Supplement of Atmos. Chem. Phys., 21, 8067-8088, 2021

https://doi.org/10.5194/acp-21-8067-2021-supplement

(C) Author(s) 2021. CC BY 4.0 License.

(c) (1)

Supplement of

\title{
Molecular characterization of gaseous and particulate oxygenated compounds at a remote site in Cape Corsica in the western Mediterranean Basin
}

Vincent Michoud et al.

Correspondence to: Vincent Michoud (vincent.michoud@lisa.ipsl.fr)

The copyright of individual parts of the supplement might differ from the article licence. 
Sect. S1: Sampling devices and TD-GC/MS analysis for the molecular characterization of multiphase organic carbon

\section{S1.1 Gaseous phase}

\section{S1.1.1 Gaseous phase sampling}

Sampling of gaseous oxygenated compounds was achieved by using commercial sorbent cartridges containing Tenax TA (porous polymers based on 2.6-diphenyl-p-phenylene oxide; Perkin Elmer ${ }^{\mathrm{TM}}$ or Markes $^{\mathrm{TM}}$ ) that has been previously impregnated with suitable derivatization agents (see below) following an improved protocol from Rossignol et al. (2012). To maximize the adsorption surface, small particle size of $60 / 80$ mesh has been selected. Ambient air samplings were performed during $6 \mathrm{~h}$ at a flow rate of $100 \mathrm{~mL} \mathrm{~min}^{-1}$. A Teflon filter (Zefluor ${ }^{\mathrm{TM}}$ membrane, Pallflex ${ }^{\mathrm{TM}}, 47 \mathrm{~mm}$ ) was installed upstream from the cartridges to trap particulate compound that could potentially be adsorbed on Tenax adsorbent. Gaseous phase sampling has been performed using individual pumps (Gilian ${ }^{\mathrm{TM}}$ pump, model LFS-113DC). Prior to sampling, cartridges were heated at $320^{\circ} \mathrm{C}$ under a small helium flow rate during $4 \mathrm{~h}$ to eliminate any trace of contamination. Every single cartridge was then analyzed to ensure its cleanliness with quantities below Limit of Detection (LOD) for all measured compounds. During the campaign, 177 gaseous samples were collected following this protocol.

\section{S1.1.2 Sample preparation for gaseous phase}

For the analysis of multi-functionalized OVOC by gas chromatography, a derivatization step is needed. It allows the suppression of the reactivity of functions, improving their thermal stability and rising their volatility. The dual derivatization reagents used in this study are PFBHA for carbonyl compounds and MTBSTFA (N-tert-Butyldimethylsilyl-N-methyltrifluoroacetamide) for hydroxyl compounds. The two derivatization processes are performed separately.

\section{S1.1.2.1 Carbonyl compounds}

PFBHA has been used as derivatization reagent for the analysis of carbonyls. Cartridges have been impregnated prior to sampling thanks to a glass balloon with 8 arms, containing $0.33 \mathrm{mg}$ of solid PFBHA per cartridges mounted on the balloon, and on which the cartridges are installed under a $100 \mathrm{~mL} \mathrm{~min}^{-1}$ nitrogen flow rate per cartridges at $110^{\circ} \mathrm{C}$ during 20 minutes. The impregnated cartridges are stored at room temperature until the sampling. After sampling, cartridges are stored at room temperature during 5 days, optimum for the derivatization step using PFBHA (Ho and Yu, 2002), before their analysis.

\section{S1.1.2.2 Hydroxyl compounds and carboxylic acids}

MTBSTFA with 1\% of TBDMCS (tert-butyldimethylchlorosilane, used as catalyst for the reaction) has been used as derivatization agent for the analysis of hydroxyl compounds. Cartridges are impregnated prior to sampling vaporizing $0.3 \mu \mathrm{L}$ of MTBSTFA at $275^{\circ} \mathrm{C}$ using a commercial thermal tube desorber (Dynatherm 
Analytical Instruments, model 890) under a flow of Helium of $30 \mathrm{~mL} \mathrm{~min}^{-1}$ for 11 minutes. The cartridges are then stored at room temperature and sampling is performed within 10 days after impregnation. After sampling, cartridges are stored at $4^{\circ} \mathrm{C}$. To ensure complete derivatization of all compounds before the analysis, two deposits of $0.3 \mu \mathrm{L}$ of MTBSTFA are achieved on each side of the cartridges which are kept at $60^{\circ} \mathrm{C}$ during $5 \mathrm{~h}$ after that. Once the cartridges are back at room temperature, analysis is performed within 5 hours.

\section{S1.2 Particulate phase}

\section{S1.2.1 Particulate phase sampling}

Sampling of particulate matter was performed over regular (not impregnated) filters and derivatization was performed only after sampling (to avoid chemisorption of gaseous compounds on filters) following a protocol adapted from Rossignol et al. (2012). The sampling device used during the campaign was a modified Speciation Sampler Partisol, model 2300 (Rupprecht \& Patashnick Co, Thermo Fisher Scientific). Three ChemComb cartridges, with $\mathrm{PM}_{2.5}$ impactors, were mounted to this device to allow the sampling of particulate phase on filters of different nature according to targeted compounds. For carbonyls compounds and non-oxygenated compounds Quartz filters (Pallflex ${ }^{\mathrm{TM}}, 47 \mathrm{~mm}$ ) were used. For hydroxyl compounds, quartz filters are not suitable because of silanol groups present at their surfaces that can be derivatized instead of the hydroxyl compounds reducing considerably their derivatization yield (Rossignol, 2012). Therefore, for the sampling of this type of compounds, we selected filters of borosilicate glass fibers coated with tetrafluoroethylene (TFE) called hereafter "Teflon quartz filters" (Fiber film, Pallflex ${ }^{\mathrm{TM}}$, $47 \mathrm{~mm}$ ). Activated carbon honeycomb denuders were installed upstream from the filters to avoid positive artifacts due to adsorption of gaseous oxygenated compounds on the filters. For cleaning and a best efficiency, denuders were heated at $250^{\circ} \mathrm{C}$ before being used for each new sample. The sampling flow rate was of $1 \mathrm{~m}^{3} \mathrm{~h}^{-1}$ for each sample step. Quartz and Teflon quartz filters were carbonized prior to the sampling respectively at $500^{\circ} \mathrm{C}$ and $300^{\circ} \mathrm{C}$ to eliminate any possible contamination. During the campaign, 240 particulate samples were collected following this protocol.

\section{S1.2.2 Sample preparation for particulate phase}

\section{S1.2.2.1 Carbonyl compounds}

Sampling are performed on quartz filters which are stored at $-16^{\circ} \mathrm{C}$ after sampling waiting for analysis. Then, the filters are cut into two pieces, both inserted into empty and clean stainless steel tubes. These tubes, including grids, are previously sonicated in several bath of ultra-pure water and acetonitrile and then are heated at $400^{\circ} \mathrm{C}$ under a flow of helium $\left(80 \mathrm{~mL} \mathrm{~min}^{-1}\right)$ during $4 \mathrm{~h}$. Deposition of $50 \mu \mathrm{L}$ of PFBHA saturated solution (acetonitrile/water (90/10, v/v) with $27 \mathrm{mg} \mathrm{mL}^{-1}$ of PFBHA) are achieved in the tubes to expose adsorbed compounds to the derivatization reagent. Tubes are then stored at room temperature during 5 days to allow derivatization of adsorbed compounds before their analysis. 
S1.2.2.2 Hydroxyl compounds and carboxylic acids

Sampling are performed on Teflon quartz filters which are stored at $-16^{\circ} \mathrm{C}$ after sampling waiting for analysis. Derivatization is performed after sampling directly on filters. Filters are put in stainless steel tubes cleaned following the same protocol than for carbonyl compounds. Tubes are then sealed and maintained vertically with $10 \mu \mathrm{l}$ of MTBSTFA put in the bottom cap for passive impregnation during $24 \mathrm{~h}$ at room temperature.

\section{S1.3 Analytical system}

The analytical system used in this study is composed by three successive modules: a thermal desorption system, a gas chromatography unit and a mass spectrometer.

The thermal desorption allows the extraction of adsorbed compounds on sample support by increasing the temperature without any preliminary solvent extraction and collecting them on a cold trap before flash injection in GC/MS instrument. The thermal desorption system (Markes ${ }^{\mathrm{TM}}$, model unity 1 ) is coupled with an automated system (Markes ${ }^{\mathrm{TM}}$, model Ultra 50:50). Thermal desorption parameters are listed in Table S1.1.

The GC/ MS instrument (Agilent Technologies Inc.) used during this study is composed by two modules:

- A GC unit, model 6890 A, associated with a capillary column Integra-Guard Rxi®-5Sil MS (stationary phase: 1.4-bis(dimethylsiloxy)phenylene dimethyl polysiloxane, length: 60m, diameter: $0.25 \mathrm{~mm}$, film thickness: $0.25 \mu \mathrm{m}$, with $5 \mathrm{~m}$ pre-column deactivated without any stationary phase; Restek Corporation).

- A Mass spectrometer, model 5973N, equipped with an ionization source in EI (Electronic Impact) or $\mathrm{CI}$ (Chemical Ionization; using $\mathrm{CH}_{4}$ as reagent gas) and associated with a quadrupole.

GC/MS parameters are listed in Table S1.1. 
Table S1.1: Thermal desorption method and GC/MS parameters

\begin{tabular}{|c|c|c|}
\hline \multirow{4}{*}{$\begin{array}{l}\text { Thermal } \\
\text { desorption } \\
\text { parameters for } \\
\text { samples }\end{array}$} & temperature & $300^{\circ} \mathrm{C}$ \\
\hline & time & 15 minutes \\
\hline & flow & $50 \mathrm{~mL} \mathrm{~min}^{-1}$ \\
\hline & split flow & No split flow \\
\hline \multirow{3}{*}{$\begin{array}{l}\text { Thermal } \\
\text { desorption } \\
\text { parameters for } \\
\text { the trap } \\
\end{array}$} & Temperature & From $-10^{\circ} \mathrm{C}$ to $300^{\circ} \mathrm{C}$ \\
\hline & Time & 12 minutes \\
\hline & flow & $10 \mathrm{~mL} \mathrm{~min}^{-1}$ \\
\hline \multicolumn{2}{|c|}{ Temperature of transfer lines } & $200^{\circ} \mathrm{C}$ \\
\hline \multirow{5}{*}{ GC Parameters } & Carrier gas & $\mathrm{He}$ \\
\hline & Carrier gas flow & $1 \mathrm{~mL} \mathrm{~min}^{-1}$ \\
\hline & Temperature gradient & $40^{\circ} \mathrm{C} / 10^{\circ} \mathrm{C} \mathrm{min}^{-1} / 305^{\circ} \mathrm{C}(10 \mathrm{~min})$ \\
\hline & Split flow & $0.2 \mathrm{~mL} \mathrm{~min}^{-1}$ \\
\hline & Transfer line temperature to MS & $305^{\circ} \mathrm{C}$ \\
\hline \multirow{5}{*}{ MS parameters } & Scan $\mathrm{m} / \mathrm{z}$ & 40 to 800 \\
\hline & Solvent delay & $5 \mathrm{~min}$ \\
\hline & Quadrupole temperature & $150^{\circ} \mathrm{C}$ \\
\hline & $\begin{array}{l}\text { EI } \\
\text {-Source temperature } \\
\text {-Ionization Energy }\end{array}$ & $\begin{array}{l}230^{\circ} \mathrm{C} \\
70 \mathrm{eV}\end{array}$ \\
\hline & $\begin{array}{l}\text { CI } \\
\text {-Source temperature } \\
\text {-Reagent gas } \\
\text {-Ionization Energy }\end{array}$ & $\begin{array}{l}250^{\circ} \mathrm{C} \\
\mathrm{CH}_{4} \\
50 \mathrm{eV}\end{array}$ \\
\hline
\end{tabular}

\section{S1.4 Internal and external calibration protocol}

For a more efficient quantification, internal calibration has been set up for both family of compounds (carbonyl and hydroxyl) and for both phases. This procedure aims at taking into account drift in MS sensitivity and derivatization efficiency. Two types of internal standards are used: substitutes which are deuterated compounds getting at least one derivatized function; and an internal standard which is a compound with no derivatized function. $50 \mathrm{ng}$ of Substitutes are added prior to the derivatization step to take into account every steps of sample preparation as well as analysis steps. The list of substitutes selected is given in Table S1.2. The internal standard selected is pentadecane, because of its low volatility which limit signal variability due to evaporation of the internal standard before the analysis, and $50 \mathrm{ng}$ is added on cartridges grid just before the analysis. In addition of this internal calibration protocol, external calibrations are performed in the same conditions as atmospheric samples, doping the collecting support (i.e. whether filter or adsorbent cartridges) with known amount of external standards (list of external standards can be found in the supplementary material 4). This way, response coefficient used for quantification include the extraction efficiency and the matrix effects. In addition, recovery and matrix effect evaluation for the method can be found in Rossignol et al. (2012). 
Table S1.2 : List of substitutes used for internal calibration

\begin{tabular}{|l|l|}
\hline Substitutes used for carbonyl compounds & Substitutes used for hydroxyl compounds \\
\hline 3-methylbutanal-d2 & Pentanoic acid-d9 \\
\hline Butanal-d8 & Heptanoic acid-d13 \\
\hline 4-methyl-2-pentanone-d5 & Succinic acid-d4 \\
\hline Benzaldehyde-d6 & 2-methyl-d3-2-propyl-1,3-propanediol \\
\hline Acetophenone-d8 & Glycerol-d8 \\
\hline 2-hexanone-d5 & Tartaric acid-2,3-d2 \\
\hline 2,3-butanedione-d5 & \\
\hline 2,5-hexanedione-d10 & \\
\hline
\end{tabular}


Sect. S2: Gaseous ancillary measurements

\section{S2.1 PTR-MS}

Measurements of OVOCs (e.g. nopinone, sum of methacrolein and methyl vinyl ketone, propanoic acid and methyl ethyl ketone), among other species (e.g. aromatics and biogenic VOCs) were performed using a Proton Transfer Reaction-Time of Flight Mass Spectrometer (PTR-ToF-MS, KORE Inc ${ }^{\circledR}$ 2nd generation). A detailed description of these measurements was given by Michoud et al. $(2017,2018)$. Briefly, ambient air was sampled through a 5-m long Teflon PFA (PerFluroAlkoxy) line held at $50^{\circ} \mathrm{C}$ at a flow rate of 1.2 $\mathrm{L} \mathrm{min}-1$, leading to a residence time of 3.1s in the sampling line. The PTR-ToF-MS sampling flow rate was set at $150 \mathrm{~mL} \mathrm{~min}{ }^{-1}$. The instrument was operated at a reactor pressure and a temperature of $1.33 \mathrm{mbar}$ and $40^{\circ} \mathrm{C}$, respectively, leading to an $\mathrm{E} / \mathrm{N}$ ratio of $135 \mathrm{Td}$.

An automated zero procedure was performed every hour for $10 \mathrm{~min}$. Humid zero air was generated by passing ambient air through a catalytic converter to perform zeros at the same relative humidity than ambient air.

Signals from protonated VOCs were normalized by the signals of $\mathrm{H}_{3} \mathrm{O}^{+}$and the first water cluster $\mathrm{H}_{3} \mathrm{O}^{+}\left(\mathrm{H}_{2} \mathrm{O}\right)$ as proposed by de Gouw and Warneke (2007). Concentrations were calculated using Eq. (1):

$$
[R]=\frac{i_{R_{-} n e t}}{\left(i_{H_{3} O^{+}}+X_{r} \cdot i_{H_{3} O^{+}\left(H_{2} O\right.}\right)} \cdot \frac{150000}{R_{f, R}}
$$

Where $[R]$ represents the mixing ratio of a given $V O C, i_{R_{n} \text { net }}$ the net signal of this $V O C, \mathrm{i}_{\mathrm{H} 3 \mathrm{O}+}$ and $\mathrm{i}_{\mathrm{H3O+}+(\mathrm{H} 2 \mathrm{O})}$ the signals of $\mathrm{H}_{3} \mathrm{O}^{+}$and $\mathrm{H}_{3} \mathrm{O}^{+}\left(\mathrm{H}_{2} \mathrm{O}\right)$ at $\mathrm{m} / \mathrm{z} 19$ and 37 respectively recorded at $\mathrm{m} / \mathrm{z} 21$ and 39 to avoid any saturation of the detector and recalculated using the isotopic ratio between ${ }^{16} \mathrm{O}$ and ${ }^{18} \mathrm{O}$. $\mathrm{Xr}$ is a factor introduced to account for the effect of humidity on the PTR-MS sensitivity (de Gouw and Warneke, 2007) and is determined experimentally through calibrations performed at various relative humidity for each individual quantified VOCs. It therefore also allows to take into account the reaction pathways of each VOC with the reagent ions (i.e. $\mathrm{H}_{3} \mathrm{O}^{+}$and/or with $\mathrm{H}_{3} \mathrm{O}^{+}\left(\mathrm{H}_{2} \mathrm{O}\right) . \mathrm{R}_{\mathrm{f}, \mathrm{R}}$ is the sensitivity determined during calibration experiments (in ncts ppt ${ }^{-1}$ ) and normalized to 150000 counts s $\mathrm{s}^{-1}$ of $\mathrm{H}_{3} \mathrm{O}^{+}$ions. The latter is the number of counts of reagent ions (not corrected for ion transmission into the ToFMS) observed on this PTR-ToF-MS instrument. Data were recorded at a time resolution of $1 \mathrm{~min}$. During the campaign, calibrations were performed every 3 days using various standards, including a canister containing 15 VOCs (NMHCs, OVOCs and chlorinated VOCs; Restek ${ }^{\circledR}$ ), a gas cylinder containing 9 NMHCs (Praxair ${ }^{\circledR}$ ) and a gas cylinder containing 9 OVOCs (Praxair ${ }^{\circledast}$ ). Information about the composition of these standards can be found in Michoud et al. (2017). 
Overall uncertainties are estimated between 6 and 23\% depending on the compound considered (Michoud et al., 2017) following the "Aerosols, Clouds, and Trace gases Research InfraStructure network" (ACTRIS) guidelines for uncertainty evaluation (ACTRIS, 2012).

\section{S2.2 GC-FID/MS}

OVOCs, including aldehydes, ketones, alcohols, ethers, esters, as well as a few NMHCs, including BVOCs and aromatics, were measured using an online GC/FID-MS instrument. This instrument as well as its setup during the campaign was described by Michoud et al. (2017). Briefly, ambient air was sampled via a KI ozone scrubber and a 5-m long PFA line $\left(1 / 8^{\prime \prime}\right)$ at a flow rate of $15 \mathrm{~mL} \mathrm{~min}^{-1}$ using an Air server-unity I (Markes International ${ }^{\circledR}$ ). The sample was pre-diluted (50\% dilution) with dry zero air to keep relative humidity below $50 \%$. The sample was then collected in an internal trap, consisting in a $1.9 \mathrm{~mm}$ i.d. quartz tube filled with two different sorbents ( $5 \mathrm{mg}$ of Carbopack B and $75 \mathrm{mg}$ of Carbopack X, Supelco ${ }^{\circledR}$ ) and cooled at $12.5^{\circ} \mathrm{C}$ by a Peltier system. Compounds trapped on the sorbents were then thermally desorbed at $280{ }^{\circ} \mathrm{C}$ and injected into the column of a GC (Agilent ${ }^{\circledast}$ ) equipped with a FID for detection and quantification and with a Mass Spectrometer (MS) for identification. The compounds were separated through a high polar CP-lowox column $(30 \mathrm{~m} \times 0.53 \mathrm{~mm} \times 10 \mu \mathrm{m})\left(\operatorname{Varian}^{\circledR}\right)$. The time resolution of these measurements is $1 \mathrm{~h} 30 \mathrm{~min}$. Calibrations were performed during the campaign using a gas cylinder containing 29 VOCs (Praxair). Information about the composition of this standard can be found in Michoud et al. (2017). Overall uncertainties are estimated between 5 and $14 \%$ depending on the compound considered (Michoud et al., 2017) following ACTRIS guidelines for uncertainty evaluation (ACTRIS, 2012).

\section{S2.3 Active sampling on DNPH cartridges}

Carbonyl compounds were collected continuously for $3 \mathrm{~h}$ durations by active sampling on DNPH cartridges $\left(\right.$ Waters $\left.{ }^{\circledR}\right)$ using an automatic sampler (Tera Environment $\left.{ }^{\circledR}\right)$. Cartridges were then eluted with $3 \mathrm{~mL}$ of acetonitrile to extract these compounds; and an aliquot of $20 \mu \mathrm{L}$ was analyzed later by High Performance Liquid Chromatography (HPLC) with UV detection. Ambient air was sampled via a 3-m PFA line (1/4") at $1.5 \mathrm{~L} \mathrm{~min}^{-1}$ and passed through a KI ozone scrubber and a stainless-steel particle filter (porosity: $2 \mu \mathrm{m}$ ). More details about these measurements are given by Michoud et al. (2017; 2018). Calibrations were performed at the laboratory using Supelco ${ }^{\circledR}$ standard for DNPH. Overall uncertainties are estimated around 25\% (Michoud et al., 2017) following ACTRIS guidelines for uncertainty evaluation (ACTRIS, 2012). 
Sect. S3: Particulate ancillary measurements

\section{S3.1 ACSM}

Measurements of the chemical composition of non-refractory submicron aerosol $\left(N R-P M_{1}\right)$ have been carried out using a quadrupole ACSM (Aerodyne Research Inc., Billerica, MA, USA). These measurements have been described in detail by Michoud et al. (2017). Briefly, the calibration of this instrument with monodispersed (300 nm diameter) ammonium nitrate particles was performed 2 months before the campaign. Because ambient air was dried by a Nafion membrane and because ammonium nitrate was low during the campaign, constant collection efficiency (CE) of 0.5 has been kept. The Q-ACSM was operated continuously during the whole campaign at a time resolution of $30 \mathrm{~min}$.

\section{S3.2 Ionic Chromatography (IC)}

Soluble anions and cations were analyzed by ionic chromatography (IC, ThermoFisher ICS3000) following protocol similar to that described elsewhere (e.g. Jaffrezo et al., 1998). Briefly, $38 \mathrm{~mm}$ diameter subsamples from each filter were soaked for $20 \mathrm{~min}$ in $10 \mathrm{~mL}$ of Milli-Q water with orbital shaking, and then filtered using 0,22 $\mu \mathrm{m}$-porosity Acrodisc filters before analysis. ASA11-HC and CS16 columns were used for anions and cations analyses, respectively.

\section{S3.3 GC/MS}

Organic markers were analyzed by gas chromatography (GC) coupled with mass spectrometry (MS) using the method developed by El Haddad et al. (2011). Filter samples were first spiked with $300 \mu \mathrm{L}$ of a solution containing the internal standard D6-Cholesterol $\left(\mathrm{C}_{24} \mathrm{H}_{40} \mathrm{D}_{60}\right)$. Accelerated Solvent Extraction (ASE Dionex 300 ) was performed with a mixture of acetone/dichloromethane $(1 / 1 \mathrm{v} / \mathrm{v})$ at $100 \mathrm{bar}$ and $100^{\circ} \mathrm{C}$ during 10 min. Sample extracts were concentrated using a Turbo Vap II under $\mathrm{N}_{2}$ in a water-bath regulated at $40^{\circ} \mathrm{C}$ to a final volume of $500 \mu \mathrm{L}$. A fraction of the extracts $(50 \mu \mathrm{L})$ was derivatized at $70^{\circ} \mathrm{C}$ for $90 \mathrm{~min}$ by adding $100 \mu \mathrm{L}$ of N,O-bis(triméthylsilyl)trifluoroacétamide (BSTFA containing 1\% of TMCS). Derivatized extracts were then analyzed using a Thermo Trace Ultra GC coupled with a Polaris Q - ion trap operating in the electron impact mode. The GC was equipped with a TR-5MS capillary column ( $30 \mathrm{~m} \times 0.25 \mathrm{~mm}$ i.d. $\times 0.25$ $\mu \mathrm{m}$ film thickness). Aliquots of $1 \mu \mathrm{L}$ were injected in split mode (split ratio 50 ) at $280^{\circ} \mathrm{C}$. The column temperature program was held at $65^{\circ} \mathrm{C}$ hold for $2 \mathrm{~min}$, and ramped at $6^{\circ} \mathrm{C} / \mathrm{min}$ up to $300^{\circ} \mathrm{C}$, followed by an isothermal hold at $300^{\circ} \mathrm{C}$ for $20 \mathrm{~min}$. GC-MS response factors were determined using authentic standards. Compounds, for which no authentic standard are available, were quantified using the response factor of compounds with analogous chemical structures. Field blank filters were also treated with the same procedure. Limit of quantification are comprised between 0.02 and $0.20 \mathrm{ng} \mathrm{m}^{-3}$ and overall uncertainties are estimated between 5 and 14\% depending on the compound considered following LQ and uncertainty evaluation described by El Haddad (2011). 


\section{S3.4 HPLC}

The analysis of a large array of organic acids (including pinic and phthalic acids, and 3-MBTCA) was conducted using the same water extracts as for IC analyses. In brief, this was performed by HPLC-MS (GP40 Dionex with a LCQ-FLEET Thermos-Fisher ion trap), with negative mode electrospray ionization. The separation column is a Synergi $4 \mu \mathrm{m}$ Fusion - RP 80A ( $250 \times 3 \mathrm{~mm}$ ID, $4 \mu \mathrm{m}$ particle size, from Phenomenex). An elution gradient was optimized for the separation of the compounds, with a binary solvent gradient consisting of $0.1 \%$ formic acid in acetonitrile (solvent $\mathrm{A}$ ) and $0.1 \%$ aqueous formic acid (solvent $\mathrm{B}$ ) in various proportions during the 40-minute analytical run (see table S3.1). Column temperature was maintained to $30{ }^{\circ} \mathrm{C}$. Eluent flow rate was $0.5 \mathrm{ml} \mathrm{min}^{-1}$, and injection volume was $250 \mu \mathrm{l}$. Calibrations were performed for each analytical batch with solutions of authentic standards. All standards and samples were spiked with internal standards (phthalic-3,4,5,6-d4 acid and succinic-2,2,3,3-d4 acid). The calculation of the final atmospheric concentrations was corrected with the concentrations of internal standards and of the procedural blanks, taking also into account the extraction efficiency varying between $76-116 \%$ (depending on the acid).

Table S3.1: Elution Gradient conditions used for HPLC-ESI-MS

\begin{tabular}{|c|cc|}
\hline $\begin{array}{c}\text { Time } \\
\text { (min) }\end{array}$ & $\begin{array}{c}\text { \%A (0.1\% aqueous formic } \\
\text { acid) }\end{array}$ & $\begin{array}{c}\text { \% B (0.1\% formic acid in } \\
\text { acetonitrile })\end{array}$ \\
\hline $\begin{array}{c}\text { Initial } \\
\text { step }\end{array}$ & $\mathbf{5}$ & $\mathbf{9 5}$ \\
\hline $\mathbf{0}$ & 5 & 95 \\
$\mathbf{2 0}$ & 56 & 44 \\
$\mathbf{2 2}$ & 95 & 5 \\
$\mathbf{2 7}$ & 95 & 5 \\
$\mathbf{2 9}$ & 5 & 95 \\
$\mathbf{3 5}$ & 5 & 95 \\
\hline
\end{tabular}

\section{S3.5 OCEC SUNSET field instrument}

Concentrations of elemental carbon (EC) and organic carbon $(\mathrm{OC})$ in $\mathrm{PM}_{2.5}$ were obtained in the field from an OCEC Sunset field instrument (Sunset Laboratory, Forest Grove, OR, USA; Bae et al., 2004) operated at a flow rate of $8 \mathrm{~L} \mathrm{~min}^{-1}$ with a denuder set upstream to avoid adsorption of semi-volatile compounds on the filter collecting particles in the instrument. Data were obtained every 2 hours with this instrument.

\section{S3.6 PILS-TOC}

$\mathrm{PM}_{1}$ water-soluble organic compounds (WSOCs) were measured by a modified PILS (Brechtel Manufacturing Inc., USA; Sorooshian et al., 2006) coupled with an analyzer of total organic carbon (TOC; model Sievers 900; Ionics Ltd, USA). Sciare et al. (2011) and Michoud et al. (2017) described this technique and operating procedures used during the ChArMEx field campaign. Briefly, the PILS-TOC instrument was operated at a flow rate of $15 \mathrm{~L} \mathrm{~min}^{-1}$ with a dilution factor of 1.30. A $0.45 \mu \mathrm{m}$ pore size diameter filter in 
polyethylene was set in-line in the aerosol liquid flow to analyze the water-soluble OC fraction only and a VOC denuder was set upstream the collection to avoid semi-volatile VOC contamination. Daily blanks were conducted every day for $1 \mathrm{~h}$ by placing a total filter upstream of the sampling system.

\section{S3.7 HULIS measurements}

The water soluble HULIS fraction is analyzed according to a protocol described in detail in Baduel et al. (2009). Briefly, the water-soluble fractions obtained from aerosol samples are passed through a weak anion exchange resin (GE Healthcare ${ }^{\circ}$, HiTrap ${ }^{T M}$ DEAE FF, $0.7 \mathrm{~cm}$ ID $\times 2.5 \mathrm{~cm}$ length) without any pretreatment. After this concentration step, the organic matter adsorbed is washed with $12 \mathrm{~mL}$ of a solution of $\mathrm{NaOH}$ 0.04M (J.T.Baker ${ }^{\circ}$, pro analysis) to remove neutral components, hydrophobic bases, inorganic anion, mono- and di-acids initially retained in the resin. Finally, HULIS ws are quickly eluted in a single broad peak using $4 \mathrm{~mL}$ of a high ionic strength solution of $\mathrm{NaCl} 1 \mathrm{M}$ (Normapur ${ }^{\circ}$ ). All flow rates are set at $1.0 \mathrm{~mL}$ $\mathrm{min}^{-1}$. UV-Vis absorption spectra are measured on-line after the extraction system, using a diode array detector (Dionex UV-VIS 340U), and recorded in the range 220-550nm. The HULISws fraction is subsequently collected manually and the carbon content is analyzed with a DOC analyser (Shimadzu TOC$\left.\mathrm{V}_{\mathrm{CPH} / \mathrm{CPN}}\right)$ by catalytic burning at $680^{\circ} \mathrm{C}$ in oxygen followed by non-dispersive infrared detection of the evolved $\mathrm{CO}_{2}$. 
DMM : Derivatized Molar Mass ; MM : Molar Mass ; MS : Mass Spectra ; RT : Retention Time ; DL: Detection Limit ; QL : Quantification Limit ; ND : Not Detected

\begin{tabular}{|c|c|c|c|c|c|c|c|c|c|c|c|c|c|c|c|c|}
\hline \multirow[b]{3}{*}{ Main Fragments } & \multicolumn{8}{|c|}{ Identification } & \multicolumn{8}{|c|}{ Quantification } \\
\hline & \multirow[b]{2}{*}{ DMM } & \multirow{2}{*}{$\begin{array}{c}\begin{array}{c}\text { Number } \\
\text { of } \\
\text { functions }\end{array} \\
\text { fon }\end{array}$} & \multirow[b]{2}{*}{ MM } & \multirow[b]{2}{*}{$\mathrm{RT}(\min )$} & \multirow[b]{2}{*}{ Name } & \multirow[b]{2}{*}{ Structure } & \multirow{2}{*}{$\begin{array}{c}\text { O/C } \\
\text { Log (Saturation } \\
\text { Vapor Pressure) }\end{array}$} & \multirow[b]{2}{*}{ Identification methods } & \multirow[b]{2}{*}{ Substitute } & \multirow[b]{2}{*}{ External standard } & \multicolumn{2}{|c|}{ Gaseous Phase } & \multicolumn{2}{|c|}{ Particulate phase } & \multirow[b]{2}{*}{$\begin{array}{l}\mathrm{DL} / \mathrm{QL} \\
\left(\mathrm{ng} / \mathrm{m}^{3}\right)\end{array}$} & \multirow[b]{2}{*}{$\begin{array}{c}\text { Uncertainty } \\
\left(\mathrm{ng} / \mathrm{m}^{3}\right)\end{array}$} \\
\hline & & & & & & & & & & & $\mathrm{m} / \mathrm{z}$ integrated & $\begin{array}{c}\text { Concentration } \\
\left(\mathrm{ng} / \mathrm{m}^{3}\right)\end{array}$ & $\mathrm{m} / \mathrm{z}$ integrated & $\begin{array}{l}\text { Concentrati } \\
\text { on }\left(\mathrm{ng} / \mathrm{m}^{3}\right)\end{array}$ & & \\
\hline & \multicolumn{14}{|c|}{ Carbonyl Compounds } & & \\
\hline EI : $117,161,181,236$ & 253 & 1 & 58 & 12.77 & Propanal & & $\begin{array}{l}0.33 \\
10^{-0.5} \\
\end{array}$ & $\begin{array}{c}\text { Standard } \\
\text { Rossignol (2012) } \\
\text { Müller et al. (2006) }\end{array}$ & Butanal-d8 & Pentanal & 181 & $200 \pm 69$ & 181 & $10 \pm 1$ & $\begin{array}{c}\text { Gas } \\
0.07 / 0.22 \\
\text { Particle } \\
0.08 / 0.27 \\
\end{array}$ & $\begin{array}{c}\text { Gas } \\
69 \\
\text { Particle } \\
1 \\
\end{array}$ \\
\hline $\begin{array}{l}\text { EI : } 117,181,195,197, \\
198,251\end{array}$ & 251 & 1 & 56 & 12.87 & Acroleine & & $\begin{array}{l}0.33 \\
10^{-0.7}\end{array}$ & $\begin{array}{c}\text { Standard } \\
\text { Rossignol (2012) } \\
\text { Jaoui et al. (2014) } \\
\end{array}$ & 3-Methylbutanal-d2 & Methacrolein & 181 & $734 \pm 125$ & DMM & $6 \pm 1$ & $\begin{array}{c}\text { Gas } \\
0.36 / 1.22 \\
\text { Particle } \\
0.06 / 0.21 \\
\end{array}$ & $\begin{array}{c}\text { Gas } \\
119 \\
\text { Particle } \\
1 \\
\end{array}$ \\
\hline EI : $43,181,239,250,267$ & 267 & 1 & 72 & 13.29 & Methylpropanal & & $\begin{array}{l}0.25 \\
10^{-0.8} \\
\end{array}$ & $\begin{array}{c}\text { MS/RT } \\
\text { Rossignol (2012) }\end{array}$ & 3-Methylbutanal-d2 & 2-Ethylbutanal & $\mathrm{ND}$ & ND & 43 & $1 \pm 0,4$ & $\begin{array}{c}\text { Particle } \\
0.07 / 0.24\end{array}$ & $\begin{array}{l}\text { Particle } \\
0.4\end{array}$ \\
\hline EI : $43,57,181,195,250$ & 267 & 1 & 72 & 13.52 & $\begin{array}{l}\text { 2-Butanone (e Methyl Ethyl } \\
\text { Ketone) }\end{array}$ & & $\begin{array}{l}0.25 \\
10^{-0.8} \\
\end{array}$ & $\begin{array}{c}\text { Standard } \\
\text { Müller et al. (2006) }\end{array}$ & 2-Hexanone-d5 & 2-Hexanone-d5 & DMM - 181 & $230 \pm 18$ & DMM & blank & $\begin{array}{c}\text { Gas } \\
0.54 / 1.81 \\
\end{array}$ & $\begin{array}{c}\text { Gas } \\
17 \\
\end{array}$ \\
\hline EI : $41,69,181,265$ & 265 & 1 & 75 & 13.77 & Methacrolein & & $\begin{array}{l}0.25 \\
10^{-1.0}\end{array}$ & $\begin{array}{c}\text { Standard } \\
\text { Healy et al. (2008) }\end{array}$ & 3-Methylbutanal-d2 & Methacrolein & DMM & $230 \pm 16$ & DMM & $2 \pm 1$ & $\begin{array}{c}\text { Gas } \\
0.15 / 0.50 \\
\text { Particle } \\
0.06 / 0.21\end{array}$ & $\begin{array}{c}\text { Gas } \\
11 \\
\text { Particle } \\
1 \\
\end{array}$ \\
\hline $\begin{array}{l}\text { EI : } 42,56,69,99,117, \\
181,195,264,265\end{array}$ & 265 & 1 & 75 & 13.85 & $\begin{array}{l}\text { Methyl Vinyl Ketone } \\
(=3 \text {-Buten-2-one) }\end{array}$ & & $\begin{array}{l}0.25 \\
10^{-1.0}\end{array}$ & $\begin{array}{c}\text { Standard } \\
\text { Healy et al. (2008) }\end{array}$ & 2-Hexanone-d5 & 3-Buten-2-one & 181 & $539 \pm 30$ & DMM & $3 \pm 0,5$ & $\begin{array}{c}\text { Gas } \\
0.29 / 0.95 \\
\text { Particle } \\
0.04 / 0.14 \\
\end{array}$ & $\begin{array}{c}\text { Gas } \\
74 \\
\text { Particle } \\
0.5 \\
\end{array}$ \\
\hline $\begin{array}{l}\text { EI : } 41,56,131,181,195, \\
235,264\end{array}$ & 267 & 1 & 72 & 14.08 & Butanal & & $\begin{array}{l}0.25 \\
10^{-0.9}\end{array}$ & $\begin{array}{c}\text { Standard } \\
\text { Müller et al. (2006) }\end{array}$ & Butanal-d8 & Pentanal & 181 & $88 \pm 75$ & 181 & blank & $\begin{array}{c}\text { Gas } \\
0.53 / 1.76\end{array}$ & $\begin{array}{c}\text { Gas } \\
95\end{array}$ \\
\hline $\begin{array}{l}\text { EI: } 58,100,181,221,253, \\
281 \\
\text { CI }: 282,310,322\end{array}$ & 281 & 1 & 86 & 14.12 & 3-Methyl-2-butanone & & $\begin{array}{c}0.2 \\
10^{-1.2}\end{array}$ & $\begin{array}{c}\text { MS/RT/Nist } \\
\text { Rossignol (2012) }\end{array}$ & 2-Hexanone-d5 & 2-Hexanone-d5 & $\mathrm{ND}$ & $\mathrm{ND}$ & DMM & $1 \pm 1$ & $\begin{array}{c}\text { Particle } \\
0.08 / 0.27\end{array}$ & $\begin{array}{c}\text { Particle } \\
1\end{array}$ \\
\hline $\begin{array}{l}\text { EI : } 46,93,117,181,195 \\
218,281\end{array}$ & 281 & 1 & 86 & 14.55 & 3-Pentanone & & $\begin{array}{c}0.2 \\
10^{-1.3}\end{array}$ & $\begin{array}{c}\mathrm{MS} / \mathrm{RT} \\
\text { Rossignol (2012) }\end{array}$ & 2-Hexanone-d5 & 2-Butanone & 181 & $<\mathrm{QL}$ & ND & ND & $\begin{array}{c}\text { Gas } \\
0.06 / 0.20\end{array}$ & l \\
\hline $\begin{array}{l}\text { EI : } 43,71,167,181,195 \\
252,264,281, \\
\text { CI : } 282,310,322\end{array}$ & 281 & 1 & 86 & 14.87 & 2-Methylbutanal & & $\begin{array}{c}0.2 \\
10^{-1.3}\end{array}$ & $\mathrm{MS} / \mathrm{RT}$ & Butanal-d8 & Pentanal & ND & ND & 181 & $1 \pm 1$ & $\begin{array}{c}\text { Particle } \\
0.08 / 0.27\end{array}$ & $\begin{array}{l}\text { Particle } \\
1\end{array}$ \\
\hline $\begin{array}{l}\text { EI : } 41,55,69,161,181 \\
222,239\end{array}$ & 281 & 1 & 86 & 15.27 & Pentanal & & $\begin{array}{c}0.2 \\
10^{-1.4} \\
\end{array}$ & $\begin{array}{c}\text { Standard } \\
\text { Müller et al. (2006) }\end{array}$ & Butanal-d8 & Pentanal & 181 & $303 \pm 129$ & DMM - 42 & $2 \pm 0,4$ & $\begin{array}{c}\text { Gas } \\
0.07 / 0.22 \\
\text { Particle } \\
0.01 / 0.03 \\
\end{array}$ & $\begin{array}{c}\text { Gas } \\
129 \\
\text { Particle } \\
0.4 \\
\end{array}$ \\
\hline $\begin{array}{l}\text { EI: } 72,94,117,181,197 \\
236,253,277\end{array}$ & 295 & 1 & 100 & 15.77 & 2-Hexanone & & $\begin{array}{l}0.17 \\
10^{-1.7}\end{array}$ & $\begin{array}{c}\text { Standard } \\
\text { Berndt et al. (2003) }\end{array}$ & 2-Hexanone-d5 & 2-Hexanone & DMM - 42 & $85 \pm 4$ & 72 & blank & $\begin{array}{c}\text { Gas } \\
0.06 / 0.19\end{array}$ & $\begin{array}{c}\text { Gas } \\
4\end{array}$ \\
\hline $\begin{array}{l}\text { EI : } 43,181,278,293 \\
\text { CI : } 294,322,334\end{array}$ & 293 & 1 & 98 & 16.05 & 4-Hexen-3-one & & $\begin{array}{l}0.17 \\
10^{-2.0}\end{array}$ & MS/RT/Nist & I & I & $\mathrm{ND}$ & $\mathrm{ND}$ & 181 & blank & ' & ' \\
\hline
\end{tabular}


Identification and quantification of compounds during ChArMEx campaign.

DMM : Derivatized Molar Mass ; MM : Molar Mass ; MS : Mass Spectra ; RT : Retention Time ; QL : Quantification Limit ; ND : Not Detected

\begin{tabular}{|c|c|c|c|c|c|c|c|c|c|c|c|c|c|c|c|c|}
\hline \multirow[b]{3}{*}{ Main Fragments } & \multirow[b]{3}{*}{ DMM } & \multicolumn{7}{|c|}{ Identification } & \multicolumn{8}{|c|}{ Quantification } \\
\hline & & \multirow{2}{*}{$\begin{array}{c}\text { Number } \\
\text { of } \\
\text { functions }\end{array}$} & \multirow[b]{2}{*}{ MM } & \multirow[b]{2}{*}{$\mathrm{RT}(\min )$} & \multirow[b]{2}{*}{ Name } & \multirow[b]{2}{*}{ Structure } & \multirow{2}{*}{$\begin{array}{c}\text { O/C } \\
\text { Log (Saturation } \\
\text { Vapor Pressure) }\end{array}$} & \multirow[b]{2}{*}{ Identification methods } & \multirow[b]{2}{*}{ Substitute } & \multirow[b]{2}{*}{ External standard } & \multicolumn{2}{|c|}{ Gaseous Phase } & \multicolumn{2}{|c|}{ Particulate phase } & \multirow[b]{2}{*}{$\begin{array}{l}\mathrm{DL} / \mathrm{QL} \\
\left(\mathrm{ng} / \mathrm{m}^{3}\right)\end{array}$} & \multirow[b]{2}{*}{$\begin{array}{c}\text { Uncertainty } \\
\left(\mathrm{ng} / \mathrm{m}^{3}\right)\end{array}$} \\
\hline & & & & & & & & & & & $\mathrm{m} / \mathrm{z}$ integrated & $\begin{array}{c}\text { Concentration } \\
\left(\mathrm{ng} / \mathrm{m}^{3}\right)\end{array}$ & $\mathrm{m} / \mathrm{z}$ integrated & $\begin{array}{l}\text { Concentrati } \\
\text { on }\left(n g / m^{3}\right)\end{array}$ & & \\
\hline $\begin{array}{l}\text { EI : }: 43,181,278,293 \\
\text { CI : } 294,322,334\end{array}$ & 293 & 1 & 98 & 16.15 & 5-Hexen-3-one & & $\begin{array}{l}0.17 \\
10^{-1.7}\end{array}$ & MS/RT/Nist & 1 & 1 & ND & ND & 181 & blank & I & l \\
\hline $\begin{array}{l}\text { EI: } 43,98,117,131,161, \\
181,264,279\end{array}$ & 279 & 1 & 84 & 16.25 & 3-Methyl-2-butenal & & $\begin{array}{c}0.2 \\
10^{-1.5}\end{array}$ & Standard & 3-Methylbutanal-d2 & 3-Methyl-2-butenal & DMM - 15 & $<\mathrm{QL}$ & 181 & $<\mathrm{QL}$ & I & l \\
\hline $\begin{array}{l}\text { EI : } 41,55,72,86,181, \\
230,267,309\end{array}$ & 309 & 1 & 114 & 16.39 & 3-Heptanone & & $\begin{array}{l}0.14 \\
10^{-2.2}\end{array}$ & $\begin{array}{c}\text { MS/RT/Nist } \\
\text { Rossignol (2012) }\end{array}$ & 1 & I & ND & ND & DMM & $<\mathrm{QL}$ & I & I \\
\hline $\begin{array}{l}\text { EI : } 41,66,82,114,161 \\
181,239\end{array}$ & 295 & 1 & 100 & 16.48 & Hexanal & & $\begin{array}{l}0.17 \\
10^{-1.8}\end{array}$ & $\begin{array}{c}\text { MS/RT/Nist } \\
\text { Rossignol (2012) }\end{array}$ & Butanal-d8 & Pentanal & 181 & $311 \pm 247$ & 181 & $3 \pm 0,5$ & $\begin{array}{c}\text { Gas } \\
0.07 / 0.22 \\
\text { Particle } \\
0.08 / 0.27\end{array}$ & $\begin{array}{c}\text { Gas } \\
18 \\
\text { Particle } \\
0.5\end{array}$ \\
\hline $\begin{array}{l}\text { EI : } 41,99,161,181,222, \\
239,252,295\end{array}$ & 295 & 1 & 100 & 16.52 & 4-Methylpentanal & & $\begin{array}{l}0.17 \\
10^{-1.7}\end{array}$ & MS/RT/Nist & 2-Hexanone-d5 & 2-Ethylbutanal & ND & ND & 43 & $20 \pm 1$ & $\begin{array}{c}\text { Particle } \\
0.07 / 0.24\end{array}$ & $\begin{array}{l}\text { Particle } \\
\quad 1\end{array}$ \\
\hline $\begin{array}{l}\text { EI: } 128,181,253,309 \\
\text { CI : } 310,338,350\end{array}$ & 309 & 1 & 114 & 16.60 & 2-Heptanone & & $\begin{array}{l}0.14 \\
10^{-2.2}\end{array}$ & $\begin{array}{c}\text { MS/RT/Nist } \\
\text { Rossignol (2012) }\end{array}$ & 2-Hexanone-d5 & 4-Heptanone & ND & ND & DMM & $<\mathrm{QL}$ & । & , \\
\hline EI : $62,110,181,248,291$ & 291 & 1 & 96 & 17.05 & 2-Furaldehyde & & $\begin{array}{c}0.4 \\
10^{-2.1}\end{array}$ & MS/RT/Nist & Benzaldehyde-d6 & Pentanal & DMM & blank & ND & $\mathrm{ND}$ & I & ' \\
\hline $\begin{array}{l}\text { EI: } 41,67,82,112,161 \\
181,263,276,293\end{array}$ & 293 & 1 & 98 & 17.53 & Cyclohexanone & & $\begin{array}{l}0.17 \\
10^{-2.1}\end{array}$ & $\begin{array}{c}\text { MS/RT/Nist } \\
\text { Rossignol (2012) } \\
\text { Hamilton et al. (2004) }\end{array}$ & Acetophenone-d8 & 2-Butanone & 181 & $744 \pm 109$ & 181 & blank & $\begin{array}{c}\text { Gas } \\
0.09 / 0.30\end{array}$ & $\begin{array}{l}\text { Gas } \\
108\end{array}$ \\
\hline $\begin{array}{l}\text { EI }: 41,55,69,99,128, \\
161,181,222,239\end{array}$ & 309 & 1 & 114 & 17.69 & Heptanal & & $\begin{array}{l}0.14 \\
10^{-2.3}\end{array}$ & $\begin{array}{c}\text { Standard } \\
\text { Müller et al. (2006) }\end{array}$ & Butanal-d8 & Pentanal & 181 & $421 \pm 122$ & 181 & $2 \pm 0,5$ & $\begin{array}{c}\text { Gas } \\
0.07 / 0.22 \\
\text { Particle } \\
0.08 / 0.27\end{array}$ & $\begin{array}{c}\text { Gas } \\
122 \\
\text { Particle } \\
0.5\end{array}$ \\
\hline $\begin{array}{l}\text { EI : } 51,65,77,103,106, \\
167,181,258,315\end{array}$ & 315 & 1 & 120 & 18.77 & m-Tolualdehyde & & $\begin{array}{l}0.13 \\
10^{-3.3}\end{array}$ & MS/RT/Nist & Acetophenone-d8 & 3-Methyl-2-butenal & DMM & $407 \pm 47$ & ND & ND & $\begin{array}{c}\text { Gas } \\
0.05 / 0.18\end{array}$ & $\begin{array}{l}\text { Gas } \\
47\end{array}$ \\
\hline $\begin{array}{l}\text { EL : } 41,55,69,82,99,124, \\
142,169,181,222,239\end{array}$ & 323 & 1 & 128 & 18.85 & Octanal & & $\begin{array}{l}0.13 \\
10^{-2.7}\end{array}$ & $\begin{array}{c}\text { MS/RT/Nist } \\
\text { Rossignol (2012) } \\
\text { Müller et al. (2006) }\end{array}$ & Butanal-d8 & Pentanal & ND & $\mathrm{ND}$ & 181 & blank & 1 & 1 \\
\hline $\begin{array}{l}\text { EI: } 41,55,72,117,236, \\
253,280,322 \\
\text { CI: } 338,366,378\end{array}$ & 337 & 1 & 142 & 18.90 & 2,6-Dimethyl-4-heptanone & & $\begin{array}{l}0.11 \\
10^{-2.9}\end{array}$ & $\mathrm{MS} / \mathrm{RT}$ & 2-Hexanone-d5 & 4-Heptanone & ND & ND & 181 & $1 \pm 1$ & $\begin{array}{l}\text { Particle } \\
0.15 / 0.50\end{array}$ & $\begin{array}{l}\text { Particle } \\
\quad 1\end{array}$ \\
\hline $\begin{array}{l}\text { EI : } 39,51,65,77,89,181 \text {, } \\
271,301\end{array}$ & 301 & 1 & 106 & 19.20 & Benzaldehyde & & $\begin{array}{l}0.14 \\
10^{-2.8}\end{array}$ & $\begin{array}{c}\text { Standard } \\
\text { Müller et al. (2006) }\end{array}$ & Benzaldehyde-d6 & Pentanal & 181 & $586 \pm 144$ & 181 & blank & $\begin{array}{c}\text { Gas } \\
0.07 / 0.22\end{array}$ & $\begin{array}{l}\text { Gas } \\
142\end{array}$ \\
\hline $\begin{array}{l}\text { EI : } 41,50,77,106,181, \\
258,315\end{array}$ & 315 & 1 & 120 & 19.40 & Acetophenone & & $\begin{array}{l}0.13 \\
10^{-3.1}\end{array}$ & $\begin{array}{c}\text { Standard } \\
\text { Hamilton et al. (2004) }\end{array}$ & Acetophenone-d8 & 2-Butanone & $\mathrm{ND}$ & $\mathrm{ND}$ & 181 & blank & I & ' \\
\hline
\end{tabular}


Identification and quantification of compounds during ChArMEx campaign.

DMM : Derivatized Molar Mass ; MM : Molar Mass ; MS : Mass Spectra ; RT : Retention Time ; QL : Quantification Limit ; ND : Not Detected

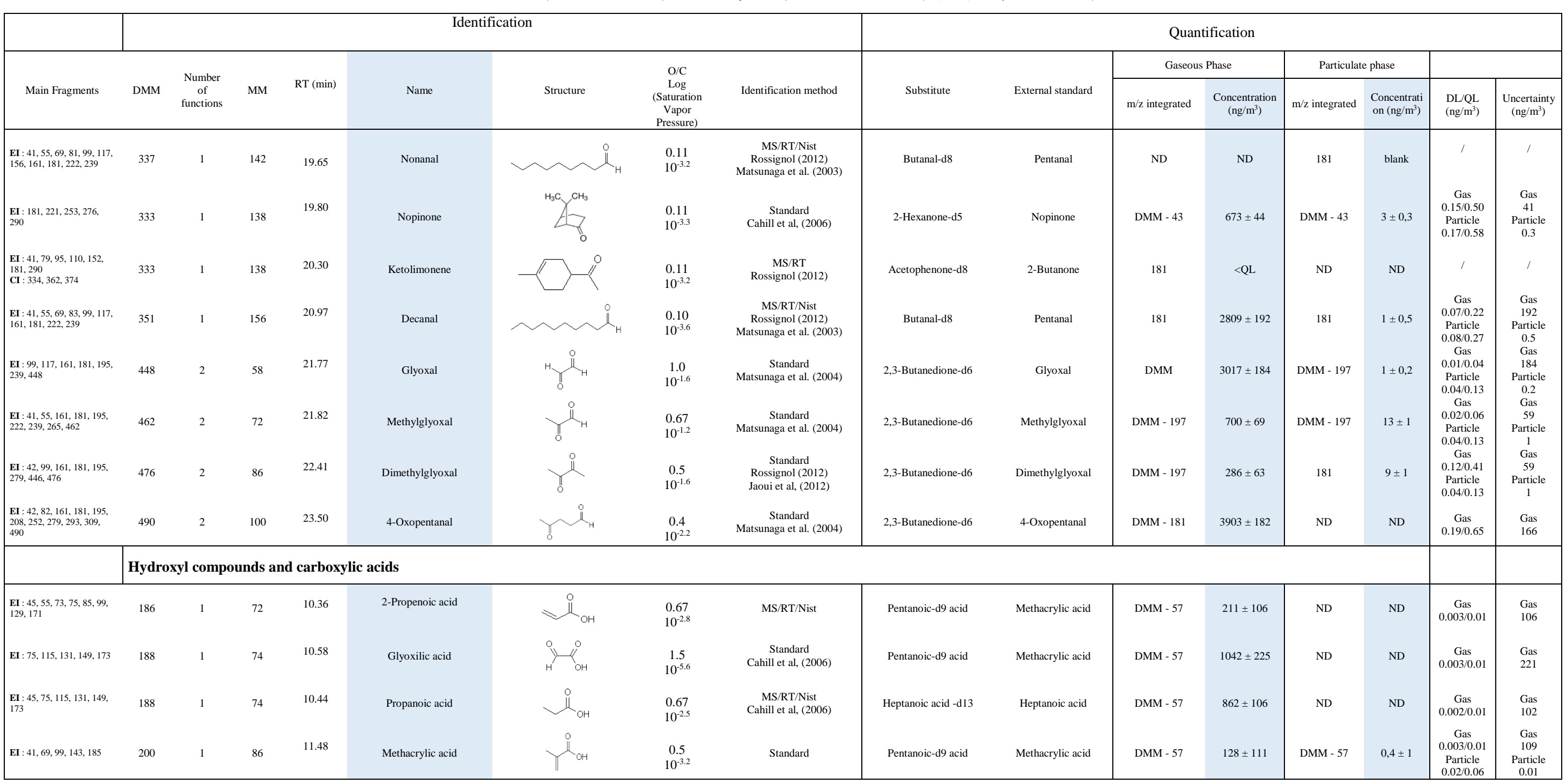


Identification and quantification of compounds during ChArMEx campaign.

DMM : Derivatized Molar Mass ; MM : Molar Mass ; MS : Mass Spectra ; RT : Retention Time ; QL : Quantification Limit ; ND : Not Detected

\begin{tabular}{|c|c|c|c|c|c|c|c|c|c|c|c|c|c|c|c|c|}
\hline \multirow[b]{3}{*}{ Main Fragments } & \multirow[b]{3}{*}{ DMM } & \multirow{3}{*}{$\begin{array}{c}\text { Number } \\
\text { of } \\
\text { functions }\end{array}$} & \multirow[b]{3}{*}{ MM } & \multirow[b]{3}{*}{$\mathrm{RT}(\mathrm{min})$} & \multicolumn{4}{|c|}{ Identification } & \multicolumn{8}{|c|}{ Quantification } \\
\hline & & & & & & & & & \multirow[b]{2}{*}{ Substitute } & \multirow[b]{2}{*}{ External standard } & \multicolumn{2}{|c|}{ Gaseous Phase } & \multicolumn{2}{|c|}{ Particulate phase } & \multirow[b]{2}{*}{$\begin{array}{l}\mathrm{DL} / \mathrm{QL} \\
\left(\mathrm{ng} / \mathrm{m}^{3}\right)\end{array}$} & \multirow[b]{2}{*}{$\begin{array}{c}\text { Uncertaint } / 7 \\
\left(\mathrm{ng} / \mathrm{m}^{3}\right)\end{array}$} \\
\hline & & & & & Name & Structure & $\begin{array}{l}\text { Log (Saturation } \\
\text { Vapor Pressure) }\end{array}$ & Identification method & & & $\mathrm{m} / \mathrm{z}$ integrated & $\begin{array}{c}\text { Concentration } \\
\left(\mathrm{ng} / \mathrm{m}^{3}\right)\end{array}$ & $\mathrm{m} / \mathrm{z}$ integrated & $\begin{array}{l}\text { Concentrati } \\
\text { on }\left(\mathrm{ng} / \mathrm{m}^{3}\right)\end{array}$ & & \\
\hline $\begin{array}{l}\text { EI }: 43,73,75,103,115 \\
145\end{array}$ & 202 & 1 & 88 & 11.96 & Pyruvic acid & & $\begin{array}{c}1 \\
10^{-3.6}\end{array}$ & $\begin{array}{c}\text { Standard } \\
\text { Kawamura et Yasui (2005) }\end{array}$ & Pentanoic-d9 acid & Pyruvic acid & DMM -57 & interferences & DMM -57 & $0,3 \pm 1$ & $\begin{array}{c}\text { Particle } \\
0.02 / 0.06\end{array}$ & $\begin{array}{l}\text { Particle } \\
0.01\end{array}$ \\
\hline EI : $41,75,99,143,185$ & 200 & 1 & 86 & 12.44 & Crotonic acid & & $\begin{array}{c}0.5 \\
10^{-3.3}\end{array}$ & Standard & Pentanoic-d9 acid & Crotonic acid & DMM - 57 & $<\mathrm{QL}$ & DMM - 57 & $2 \pm 0,5$ & $\begin{array}{c}\text { Particle } \\
0.01 / 0.03\end{array}$ & $\begin{array}{l}\text { Particle } \\
0.5\end{array}$ \\
\hline $\begin{array}{l}\text { EI : } 41,58,75,115,129 \\
159,201\end{array}$ & 216 & 1 & 102 & 13.12 & Pentanoic acid & & $\begin{array}{c}0.4 \\
10^{-3.5}\end{array}$ & Étalon & Heptanoic acid -d13 & Heptanoic acid & DMM -57 & $483 \pm 70$ & DMM - 57 & blank & $\begin{array}{c}\text { Gas } \\
0.002 / 0.01\end{array}$ & $\begin{array}{c}\text { Gas } \\
69\end{array}$ \\
\hline $\begin{array}{l}\text { EI: } 47,58,75,115,129 \\
173\end{array}$ & 230 & 1 & 116 & 13.50 & 3-Ethylbutyrique acid & & $\begin{array}{l}0.33 \\
10^{-3.9}\end{array}$ & $\mathrm{MS} / \mathrm{RT}$ & Pentanoic-d9 acid & 2-Ethylbutyric acid & DMM - 57 & $118 \pm 55$ & $\mathrm{ND}$ & ND & $\begin{array}{c}\text { Gas } \\
0.003 / 0.01\end{array}$ & $\begin{array}{c}\text { Gas } \\
64\end{array}$ \\
\hline EI : 41, 75, 131, 173, 215 & 230 & 1 & 116 & 14.51 & Hexanoic acid & & $\begin{array}{l}0.33 \\
10^{-4.0}\end{array}$ & $\begin{array}{c}\text { MS/RT/Nist } \\
\text { Rossignol (2012) }\end{array}$ & Heptanoic acid -d13 & Heptanoic acid & DMM - 57 & $722 \pm 73$ & DMM - 57 & blank & $\begin{array}{c}\text { Gas } \\
0.002 / 0.01\end{array}$ & $\begin{array}{l}\text { Gas } \\
70\end{array}$ \\
\hline $\begin{array}{l}\text { EI : } 43,75,99,129,145 \\
155,173,191,215\end{array}$ & 230 & 1 & 116 & 15.30 & Levulinic acid & & $\begin{array}{c}0.6 \\
10^{-4.6}\end{array}$ & $\begin{array}{c}\text { standard } \\
\text { Jaoui et al. (2006) }\end{array}$ & Heptanoic acid -d13 & Levulinic acid & DMM - 85 & $606 \pm 91$ & DMM - 57 & $10 \pm 1$ & $\begin{array}{c}\text { Gas } \\
0.01 / 0.04 \\
\text { Particle } \\
0.03 / 0.11\end{array}$ & $\begin{array}{c}\text { Gas } \\
83 \\
\text { Particle } \\
1\end{array}$ \\
\hline $\begin{array}{l}\text { EI }: 41,75,95,116,131, \\
187,229\end{array}$ & 244 & 1 & 130 & 15.64 & Heptanoic acid & & $\begin{array}{l}0.29 \\
10^{-4.5}\end{array}$ & $\begin{array}{c}\text { Standard } \\
\text { Rossignol (2012) }\end{array}$ & Heptanoic acid -d13 & Heptanoic acid & 131 & $399 \pm 48$ & DMM - 57 & blank & $\begin{array}{c}\text { Gas } \\
0.002 / 0.01\end{array}$ & $\begin{array}{c}\text { Gas } \\
48\end{array}$ \\
\hline \begin{tabular}{|l} 
EI $: 41,57,73,85,103$, \\
$133,147,189,219,247$
\end{tabular} & 304 & 2 & 76 & 17.27 & Glycolic acid & & $\begin{array}{c}1.5 \\
10^{-4.6}\end{array}$ & $\begin{array}{l}\text { Standard } \\
\text { Cahill et al, (2006) }\end{array}$ & Heptanoic acid -d13 & Glycolic acid & 147 & $201 \pm 67$ & 115 & $19 \pm 2$ & $\begin{array}{c}\text { Gas } \\
0.01 / 0.03 \\
\text { Particle } \\
0.01 / 0.05\end{array}$ & $\begin{array}{c}\text { Gas } \\
61 \\
\text { Particle } \\
1\end{array}$ \\
\hline $\begin{array}{l}\text { EI : 41, 57, 73, 115, 133, } \\
\text { 1477, 189, 217, 247, 275, } \\
317\end{array}$ & 332 & 2 & 104 & 17.40 & 3,3-dihydroxy-2-butanone & & $\begin{array}{l}0.75 \\
10^{-3.5}\end{array}$ & $\mathrm{MS} / \mathrm{RT}$ & Heptanoic acid -d13 & Glycolic acid & $\mathrm{ND}$ & $\mathrm{ND}$ & DMM -57 & $<\mathrm{QL}$ & I & 1 \\
\hline $\begin{array}{l}\text { EI : } 41,57,73,117,131, \\
147,189,201,231,301\end{array}$ & 316 & 2 & 88 & 17.53 & 2-Buten-1,4-diol & & $\begin{array}{c}0.5 \\
10^{-4.4}\end{array}$ & Standard & Heptanoic acid -d13 & Succinic acid & $\mathrm{ND}$ & $\mathrm{ND}$ & 147 & $<\mathrm{QL}$ & 1 & 1 \\
\hline $\begin{array}{l}\text { EI: } 41,57,73,115,147, \\
189,261,303 \\
\text {. }\end{array}$ & 318 & 2 & 90 & 17.67 & Oxalic acid & & $\begin{array}{c}2 \\
10^{-5.6}\end{array}$ & $\begin{array}{c}\text { Standard } \\
\text { Cahill et al, (2006) }\end{array}$ & Heptanoic acid -d13 & Succinic acid & DMM - 57 & $<\mathrm{QL}$ & 115 & $277 \pm 17$ & $\begin{array}{c}\text { Particle } \\
0.10 / 0.33\end{array}$ & $\begin{array}{l}\text { Particle } \\
14\end{array}$ \\
\hline $\begin{array}{l}\text { EI : } 43,57,73,99,117, \\
133,147,173,189,247, \\
275,317\end{array}$ & 332 & 2 & 104 & 17.87 & $\begin{array}{l}\text { 2-Hydroxy-2- } \\
\text { methylpropanoic acid }\end{array}$ & & $\begin{array}{l}0.75 \\
10^{-5.3}\end{array}$ & $\begin{array}{c}\text { Nist/MS/RT } \\
\text { Rossignol (2012) }\end{array}$ & Heptanoic acid -d13 & Glycolic acid & 147 & $41 \pm 100$ & DMM - 57 & blank & $\begin{array}{c}\mathrm{Gas} \\
0.01 / 0.03\end{array}$ & $\begin{array}{c}\text { Gas } \\
2\end{array}$ \\
\hline $\begin{array}{l}\text { EI : } 41,57,73,75,115, \\
133,147,189,218,303, \\
318 \\
318\end{array}$ & 318 & 2 & 90 & 18.18 & 3-Hydroxypropanoic acid & & $\begin{array}{c}1 \\
10^{-5.1}\end{array}$ & $\begin{array}{c}\text { Nist/SM/TR } \\
\text { Rossignol (2012) }\end{array}$ & Heptanoic acid -d13 & Glycolic acid & DMM - 57 & $39 \pm 62$ & DMM - 57 & $<\mathrm{QL}$ & $\begin{array}{c}\text { Gas } \\
0.01 / 0.03\end{array}$ & $\begin{array}{l}\text { Gas } \\
93\end{array}$ \\
\hline $\begin{array}{l}\text { EI : } 41,75,117,129,131 \\
171,215,257\end{array}$ & 272 & 1 & 158 & 18.45 & Nonanoic acid & & $\begin{array}{l}0.22 \\
10^{-5.5}\end{array}$ & $\begin{array}{c}\text { MS/RT/Nist } \\
\text { Rossignol (2012) }\end{array}$ & Heptanoic acid -d13 & Heptanoic acid & 131 & blank & DMM - 57 & blank & I & 1 \\
\hline
\end{tabular}


Identification and quantification of compounds during ChArMEx campaign.

DMM : Derivatized Molar Mass ; MM : Molar Mass ; MS : Mass Spectra ; RT : Retention Time ; QL : Quantification Limit ; ND : Not Detected

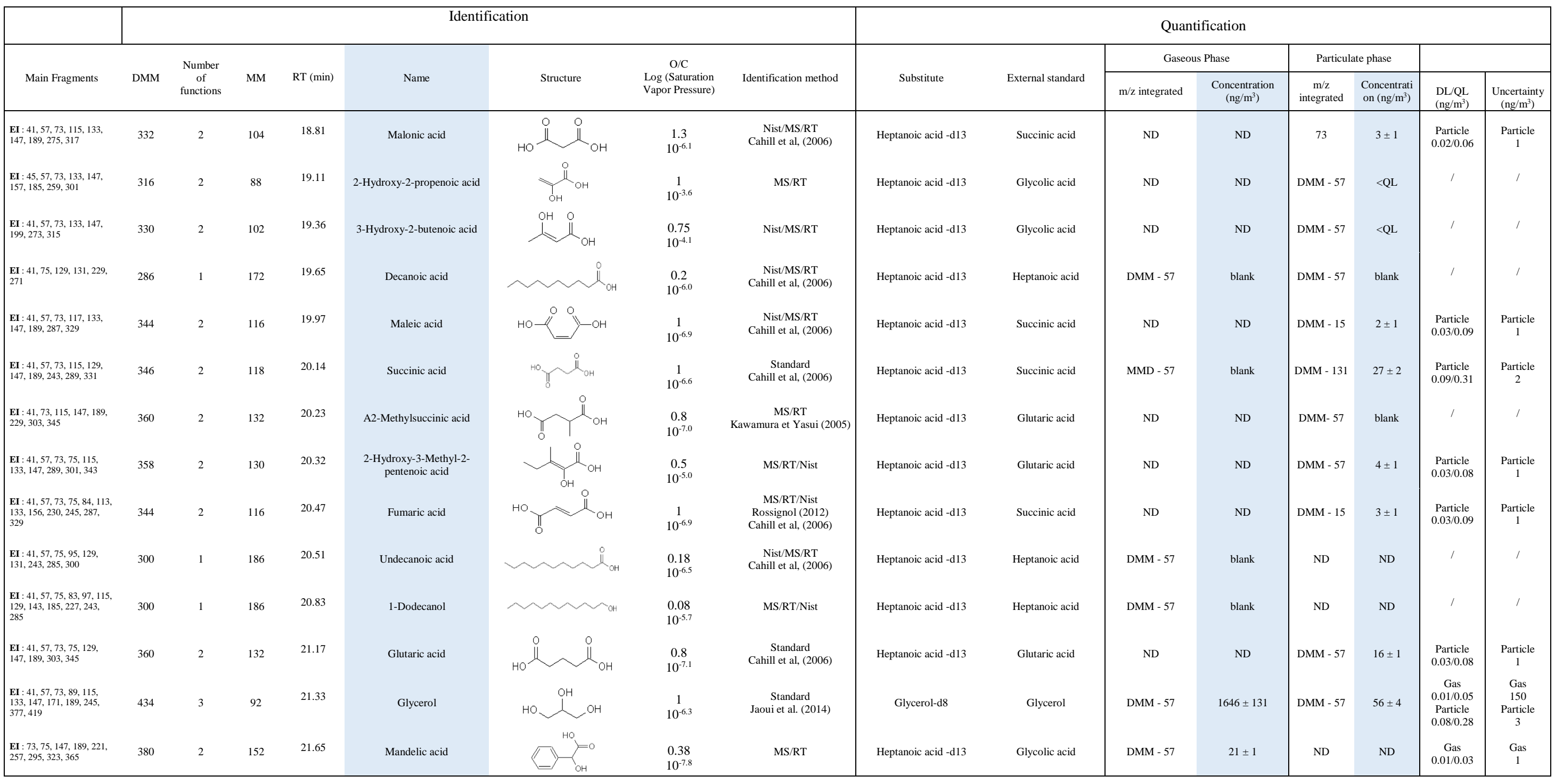


Identification and quantification of compounds during ChArMEx campaign.

DMM : Derivatized Molar Mass ; MM : Molar Mass ; MS : Mass Spectra ; RT : Retention Time ; QL : Quantification Limit ; ND : Not Detected

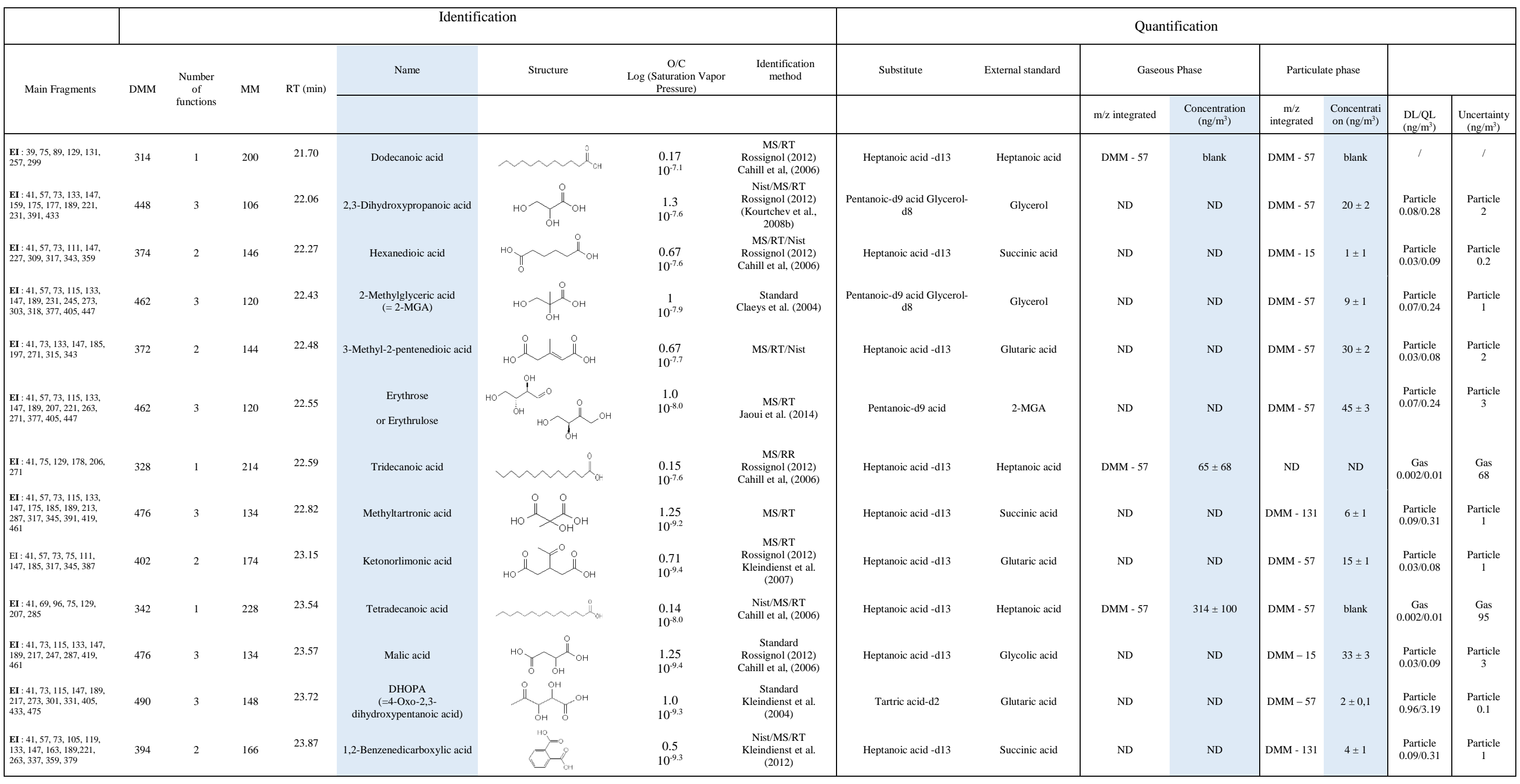


Identification and quantification of compounds during ChArMEx campaign.

DMM : Derivatized Molar Mass ; MM : Molar Mass ; MS : Mass Spectra ; RT : Retention Time ; QL : Quantification Limit ; ND : Not Detected

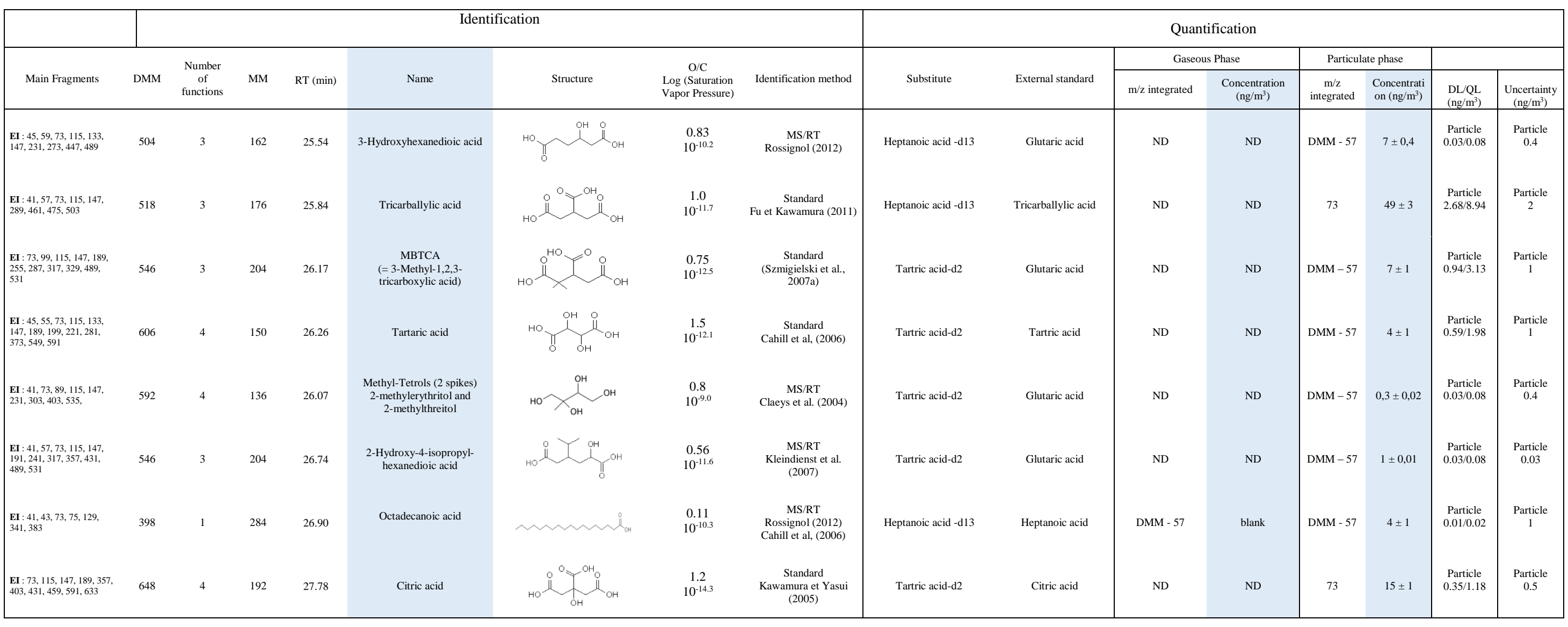


Sect. S5: Example of chromatogram for hydroxyl compounds and carboxylic acids in the gaseous phase

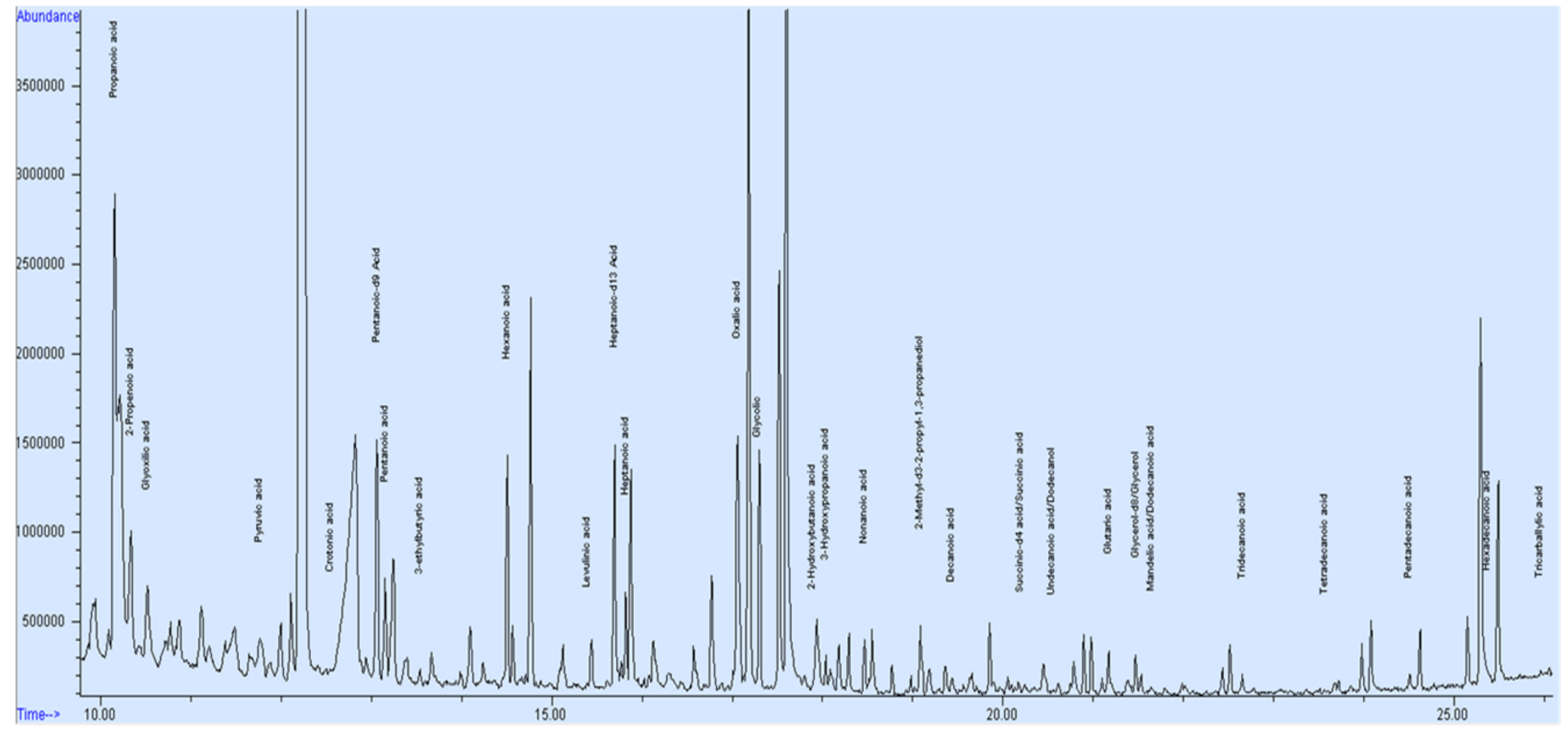


Sect. S6: Time series of compounds measured during ChArMEx campaign (in the gas phase in red and in the particulate phase in blue).
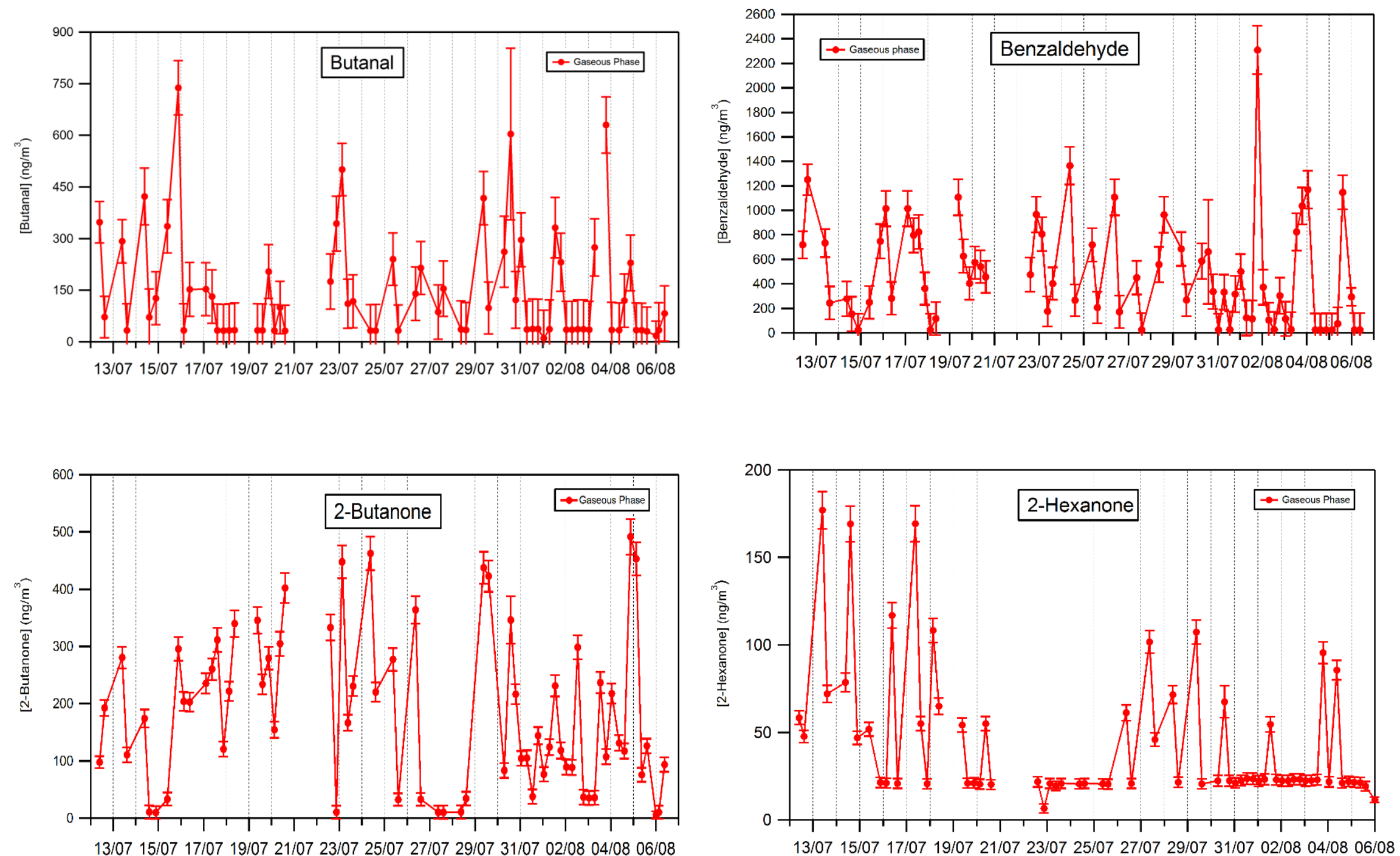

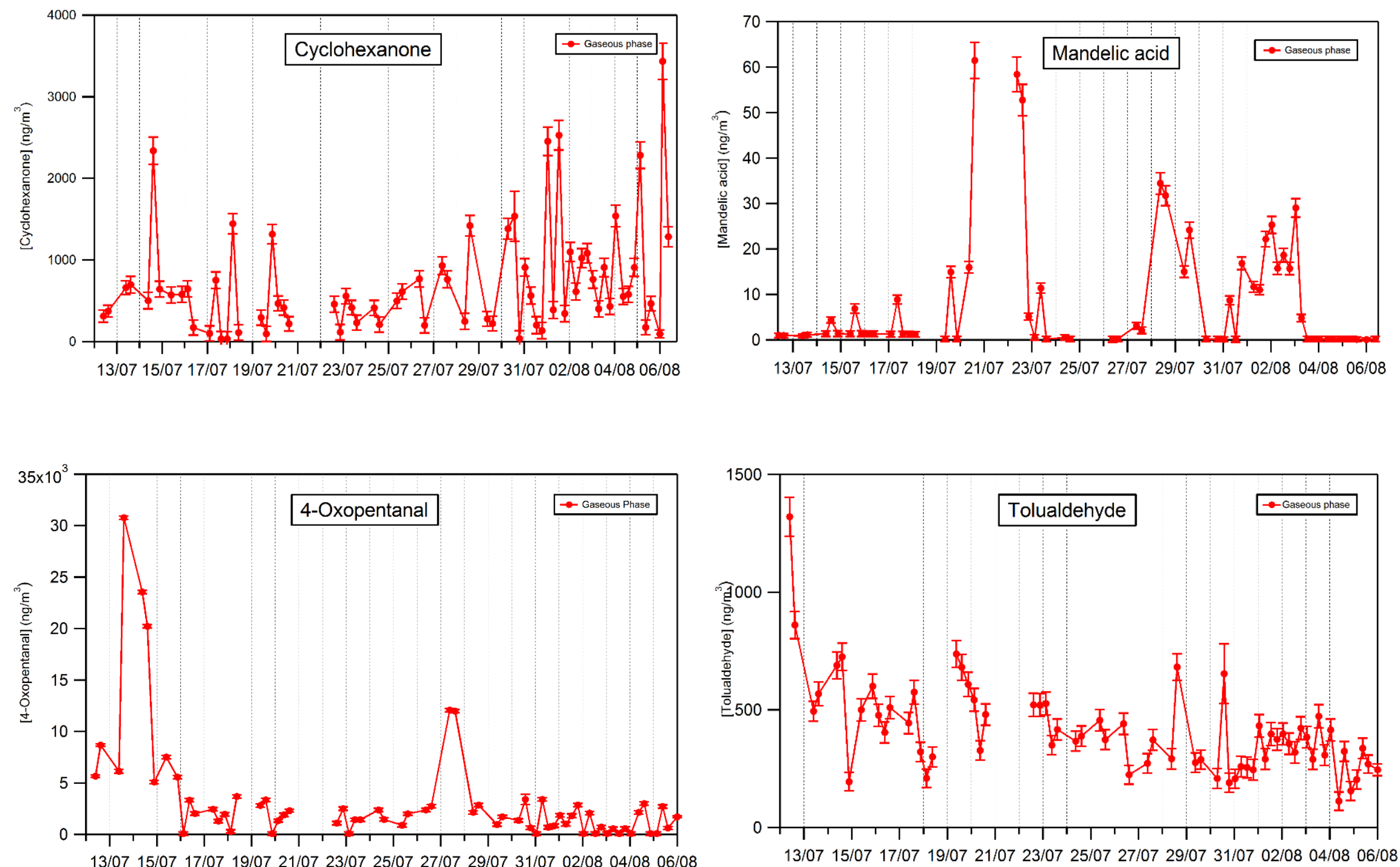

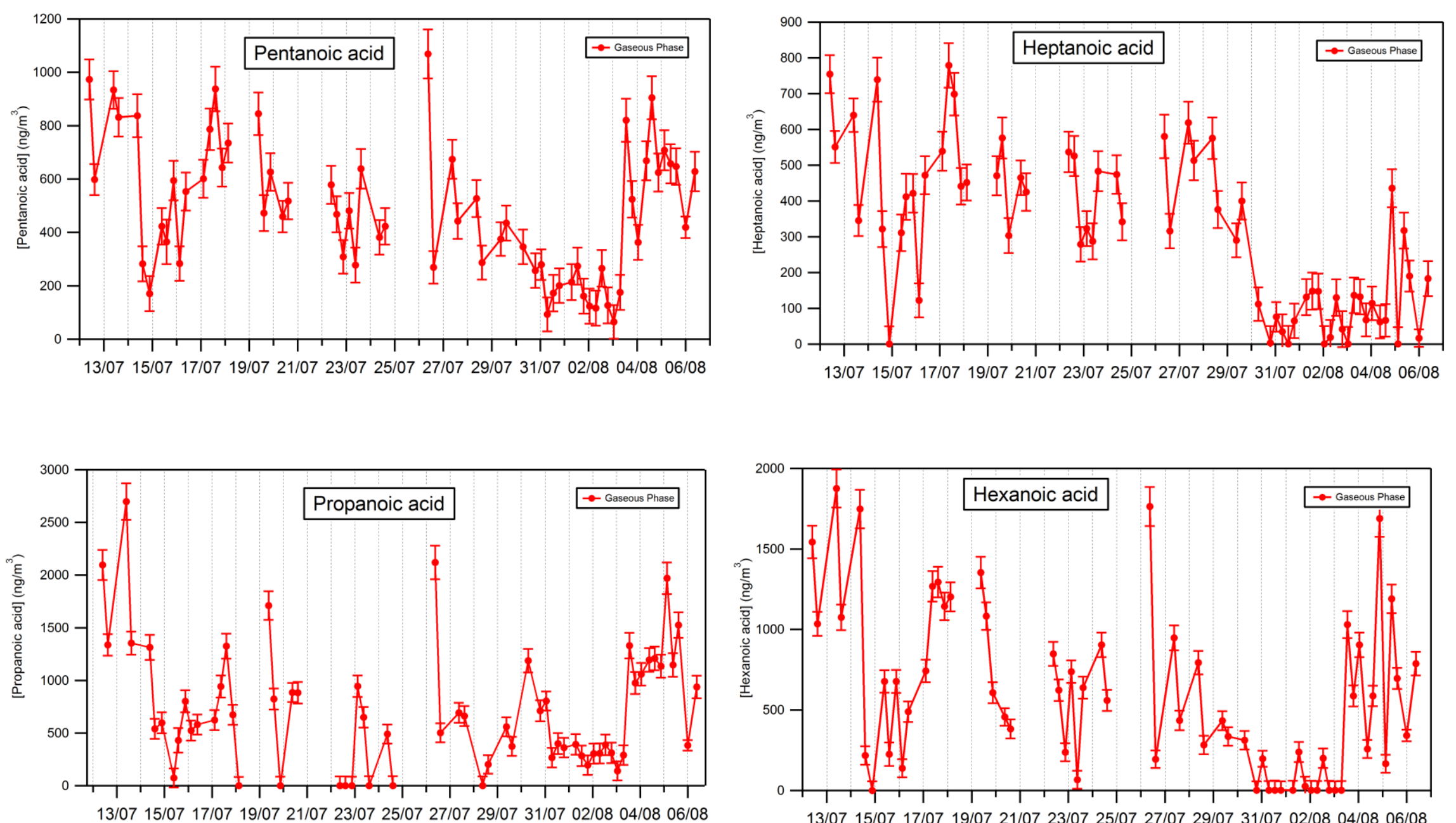

13/07 15/07 17/07 19/07 21/07 23/07 25/07 27/07 29/07 31/07 02/08 04/08 06/08

13/07 15/07 17/07 19/07 21/07 23/07 25/07 27/07 29/07 31/07 02/08 04/08 06/08 

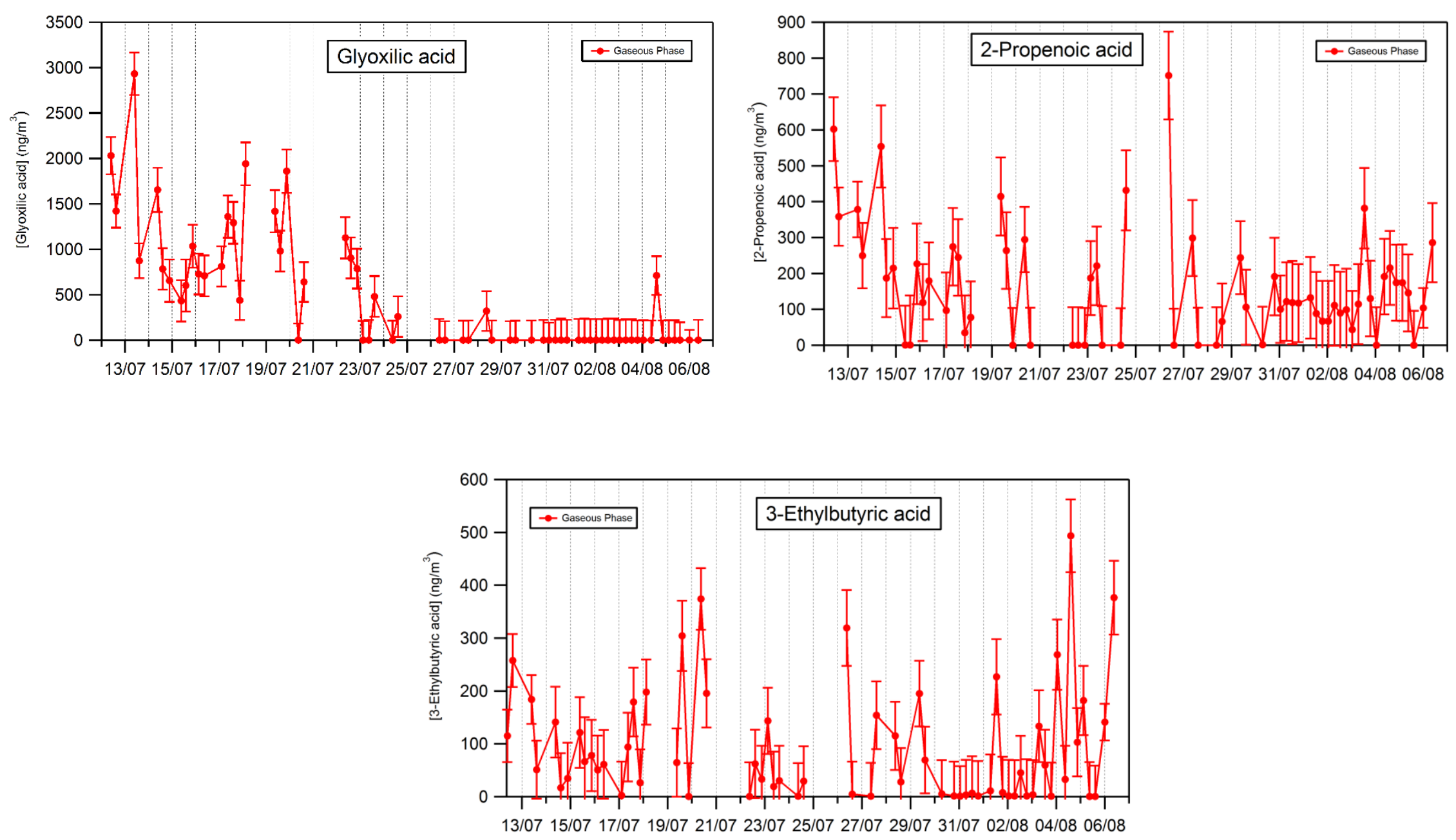

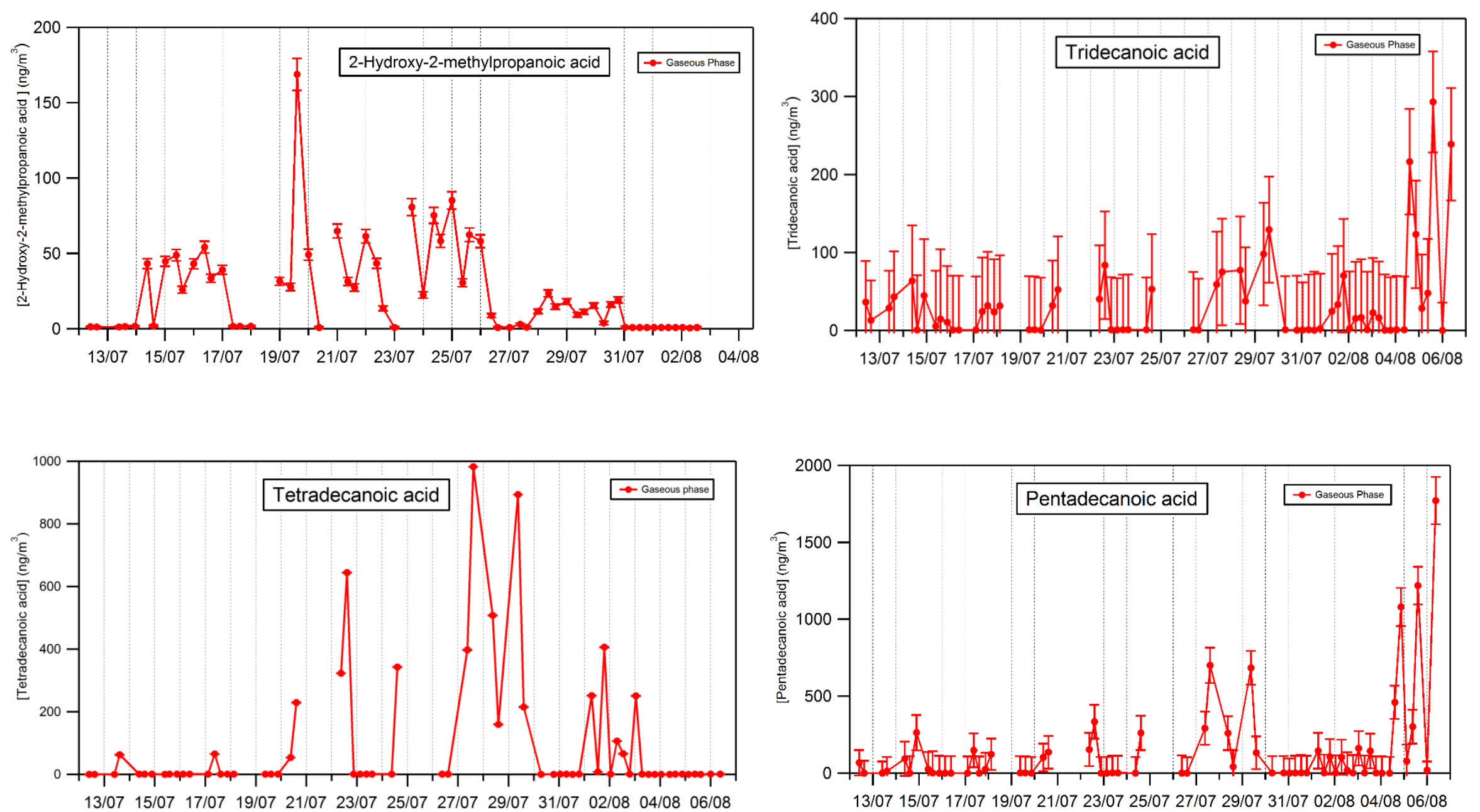

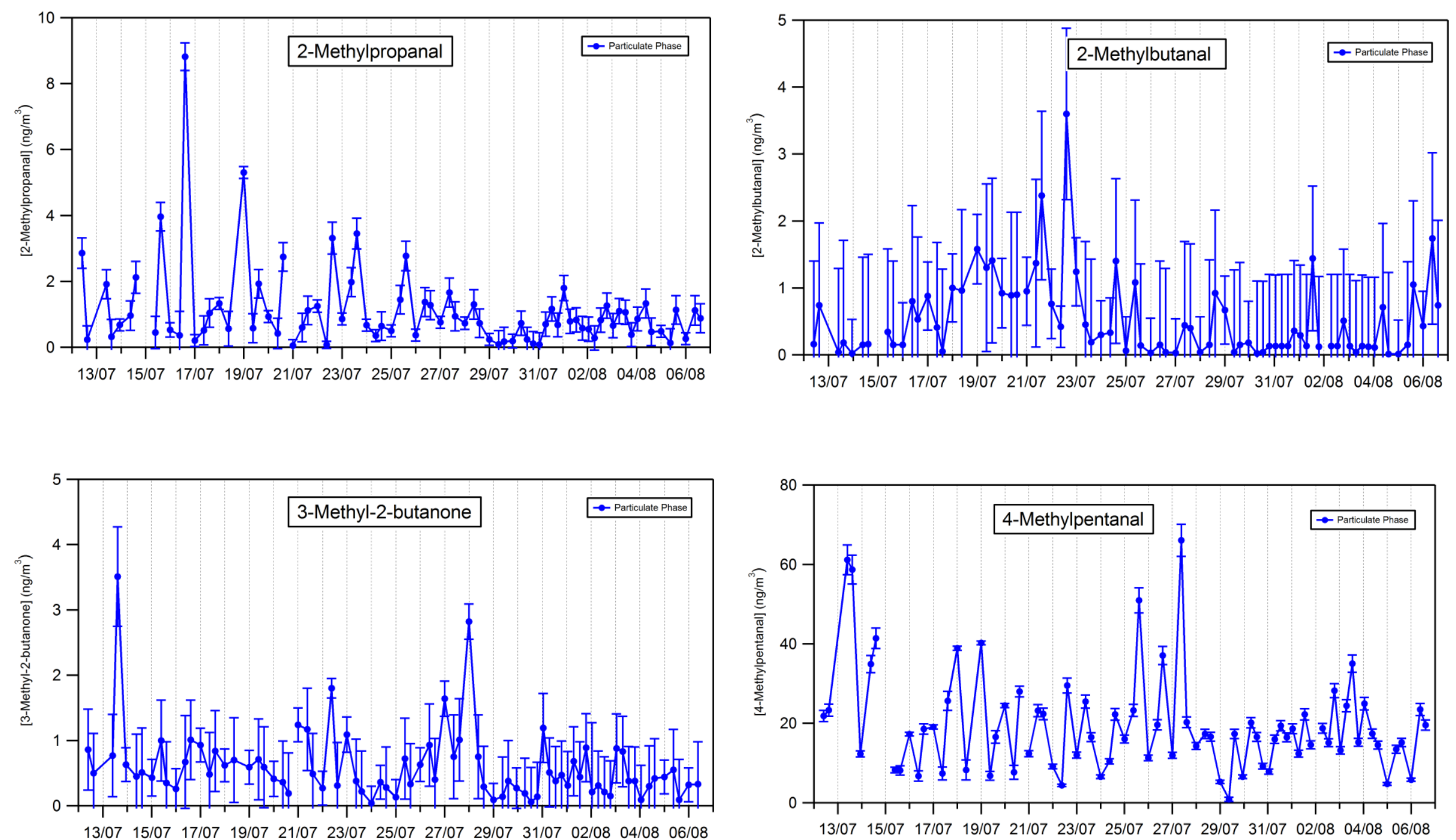

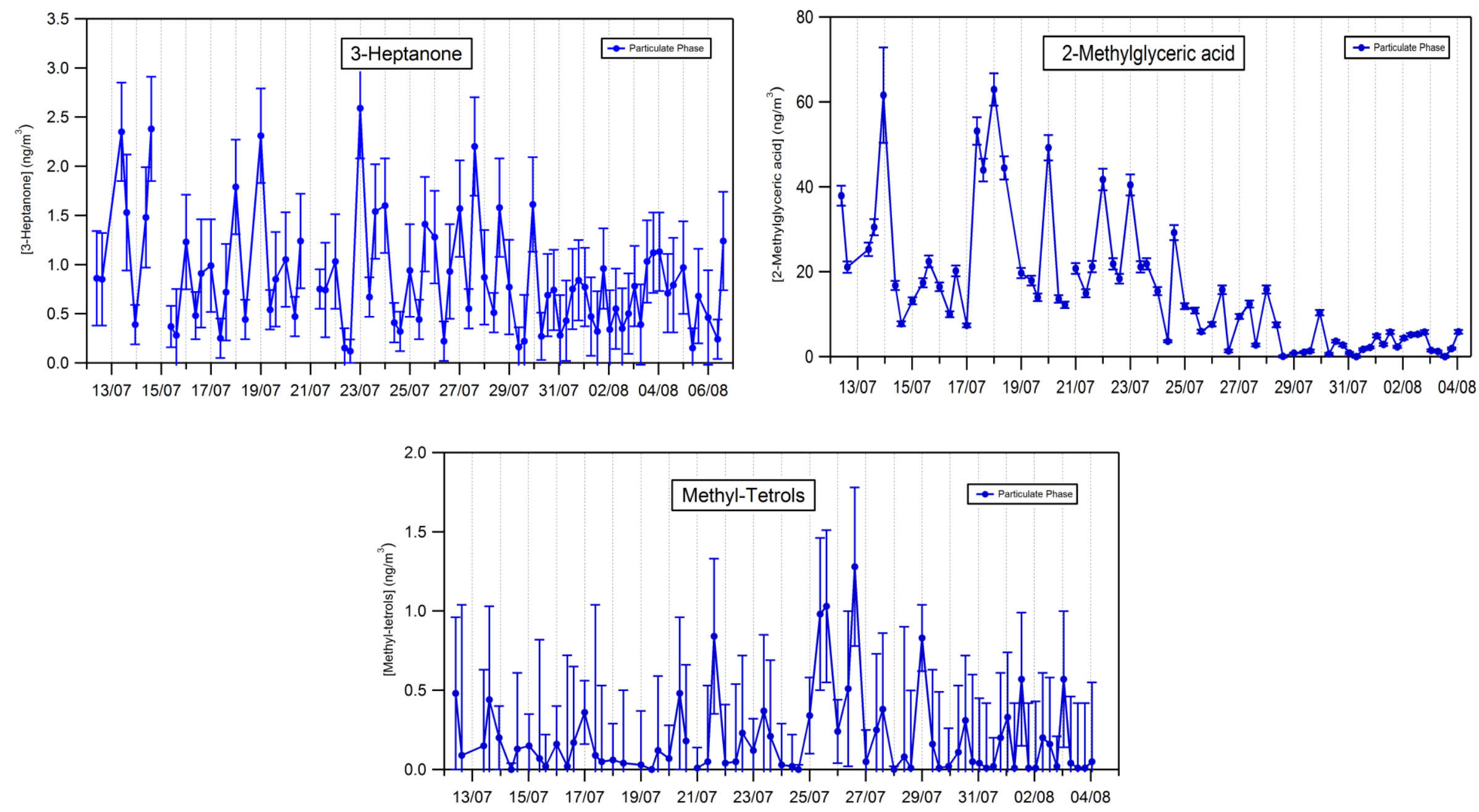

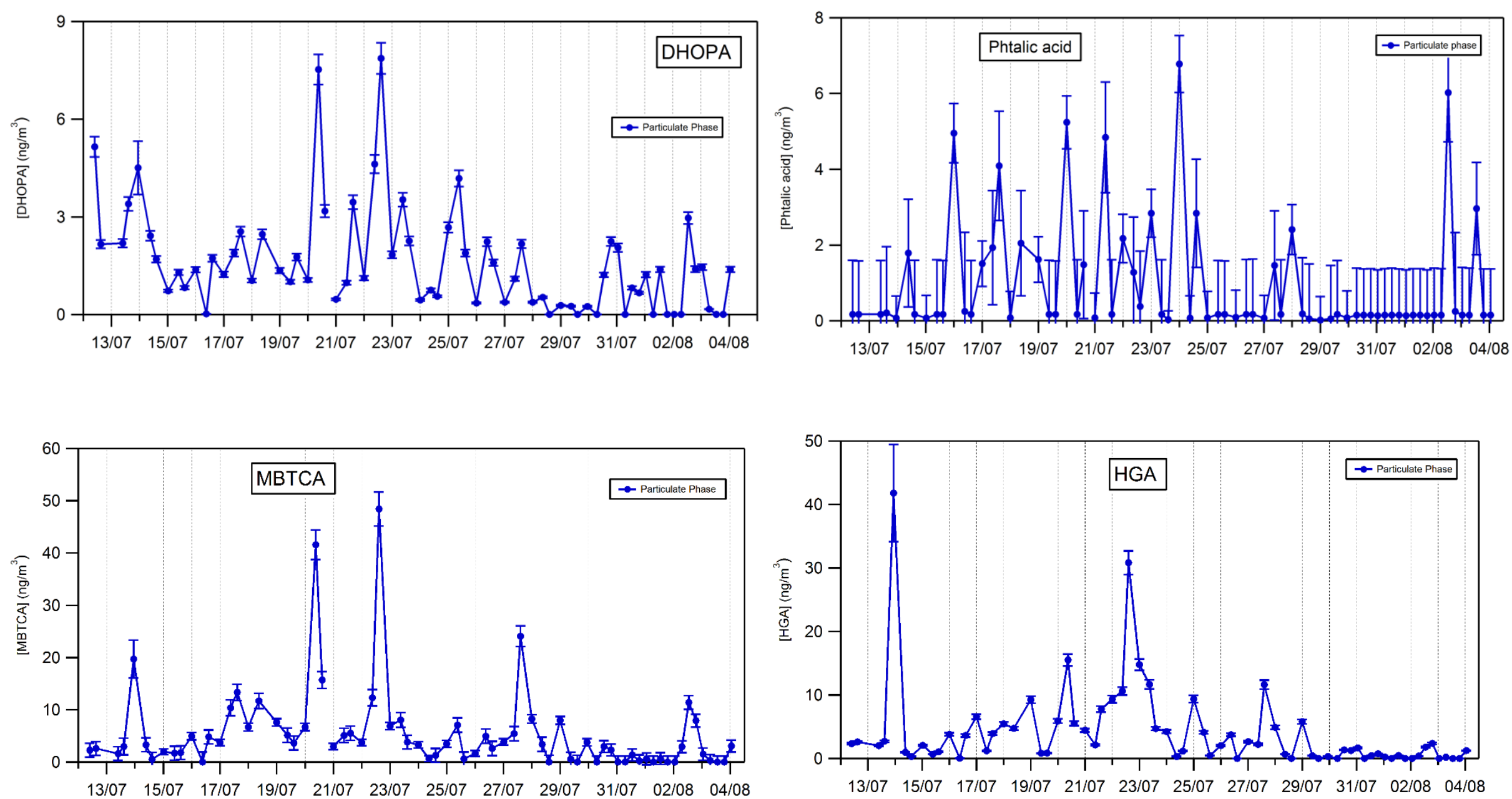

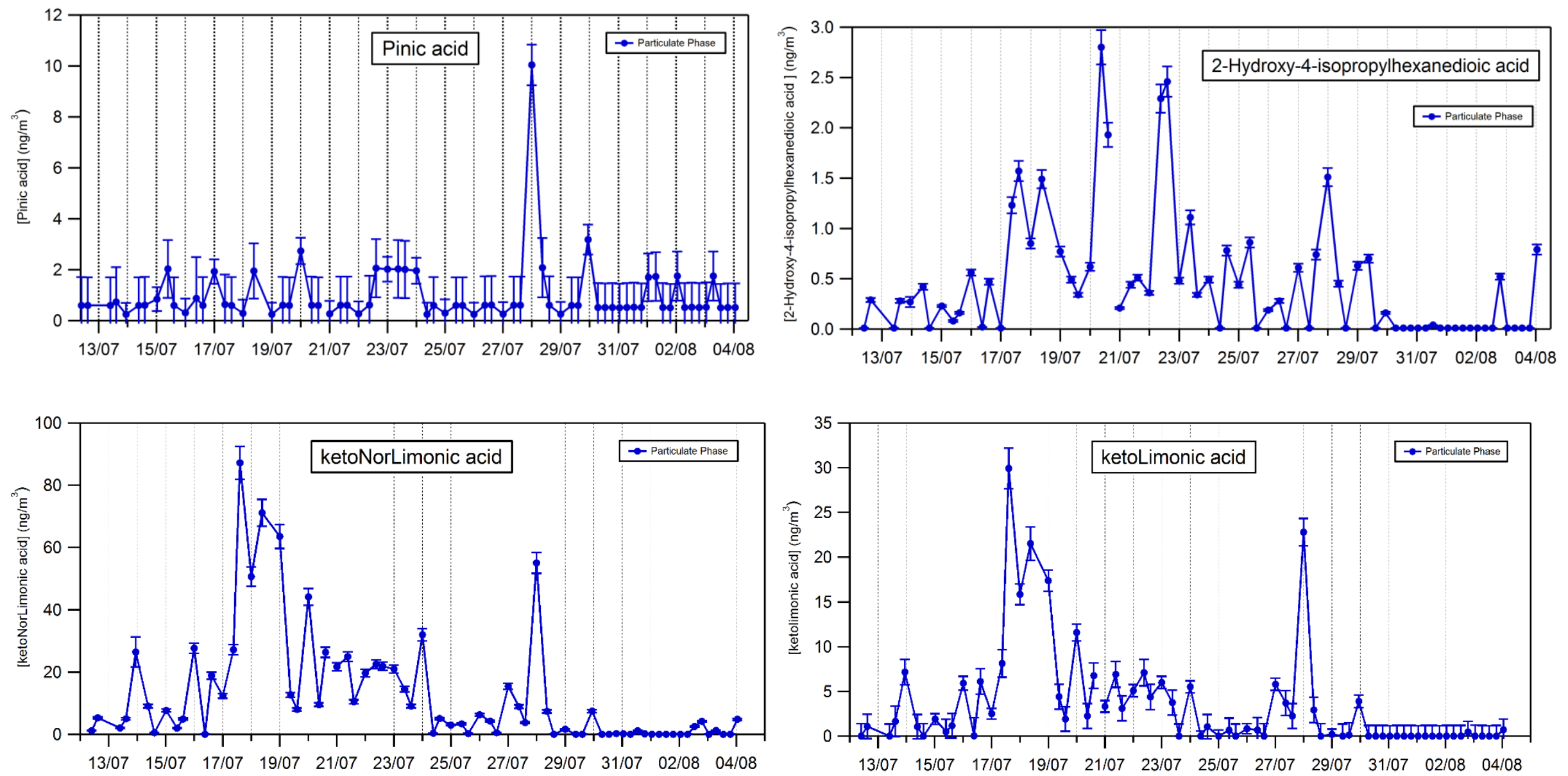

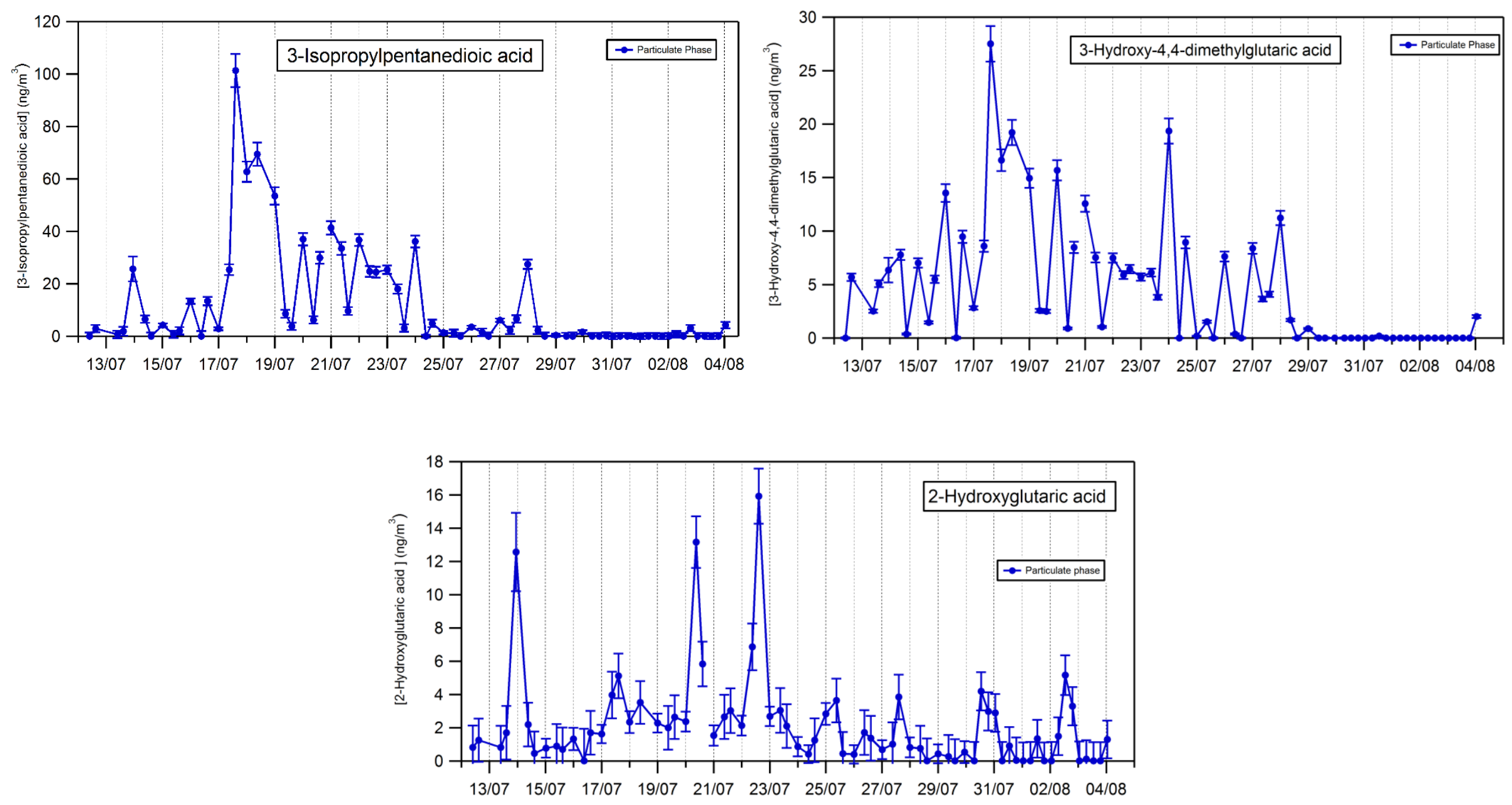

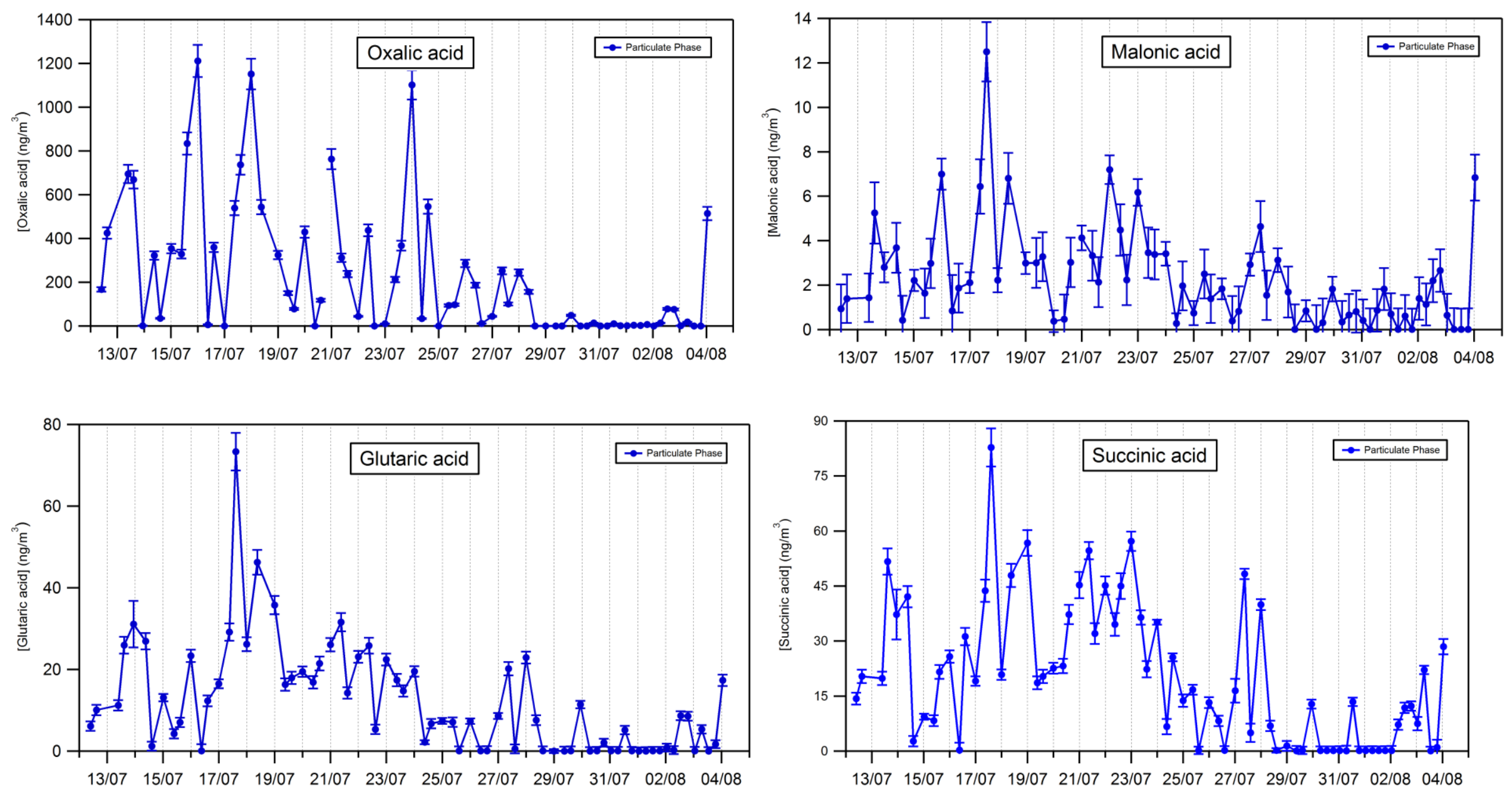

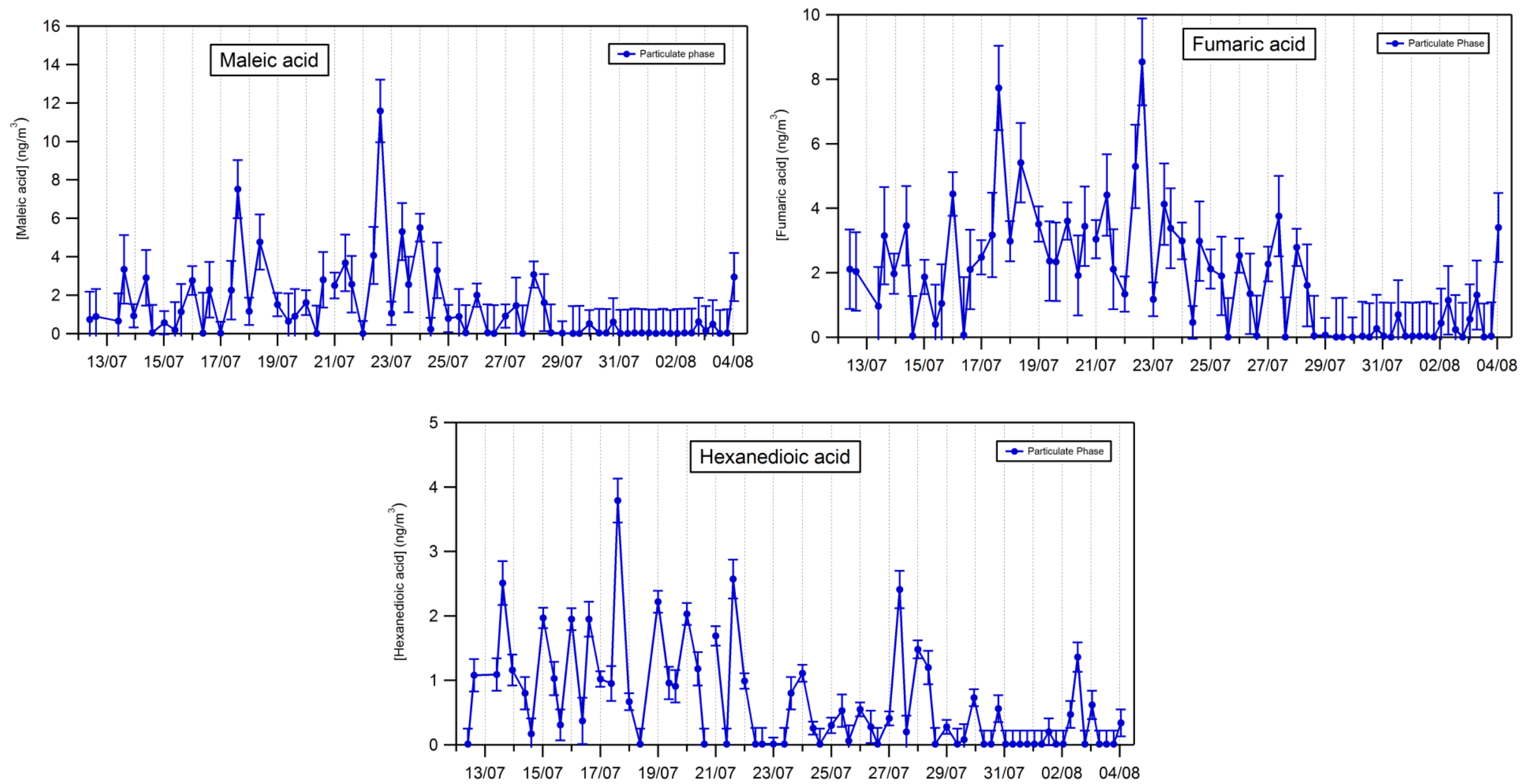

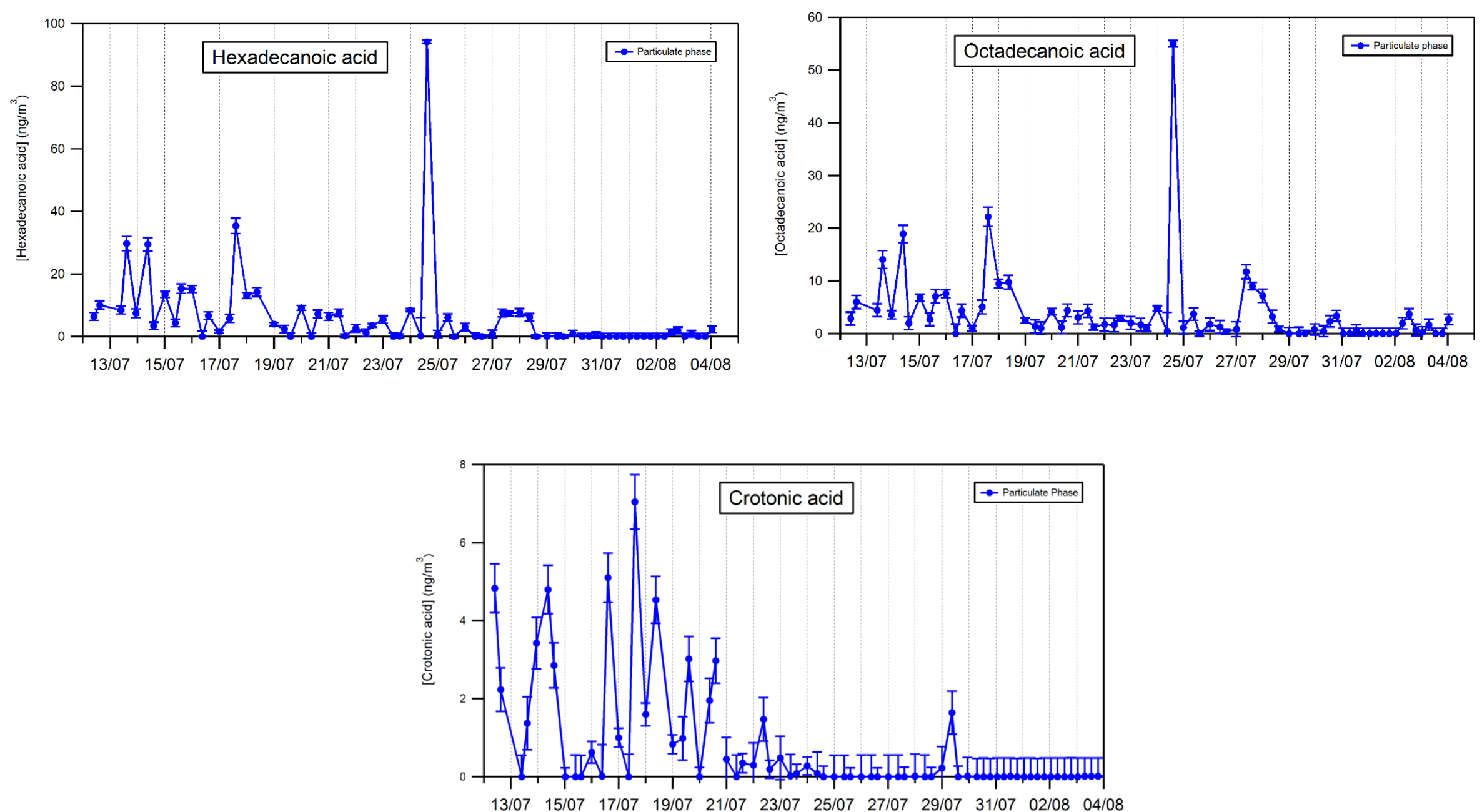

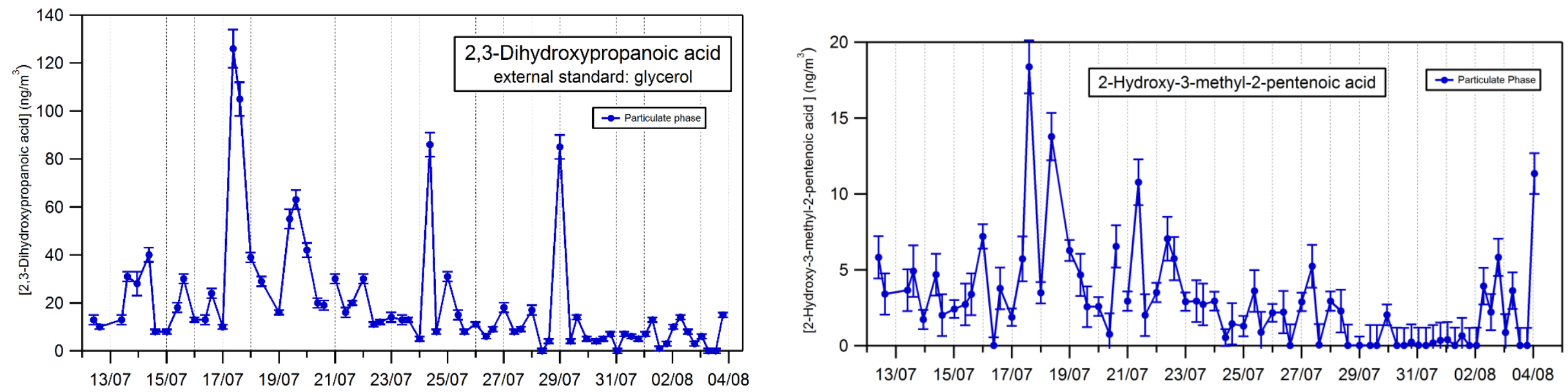

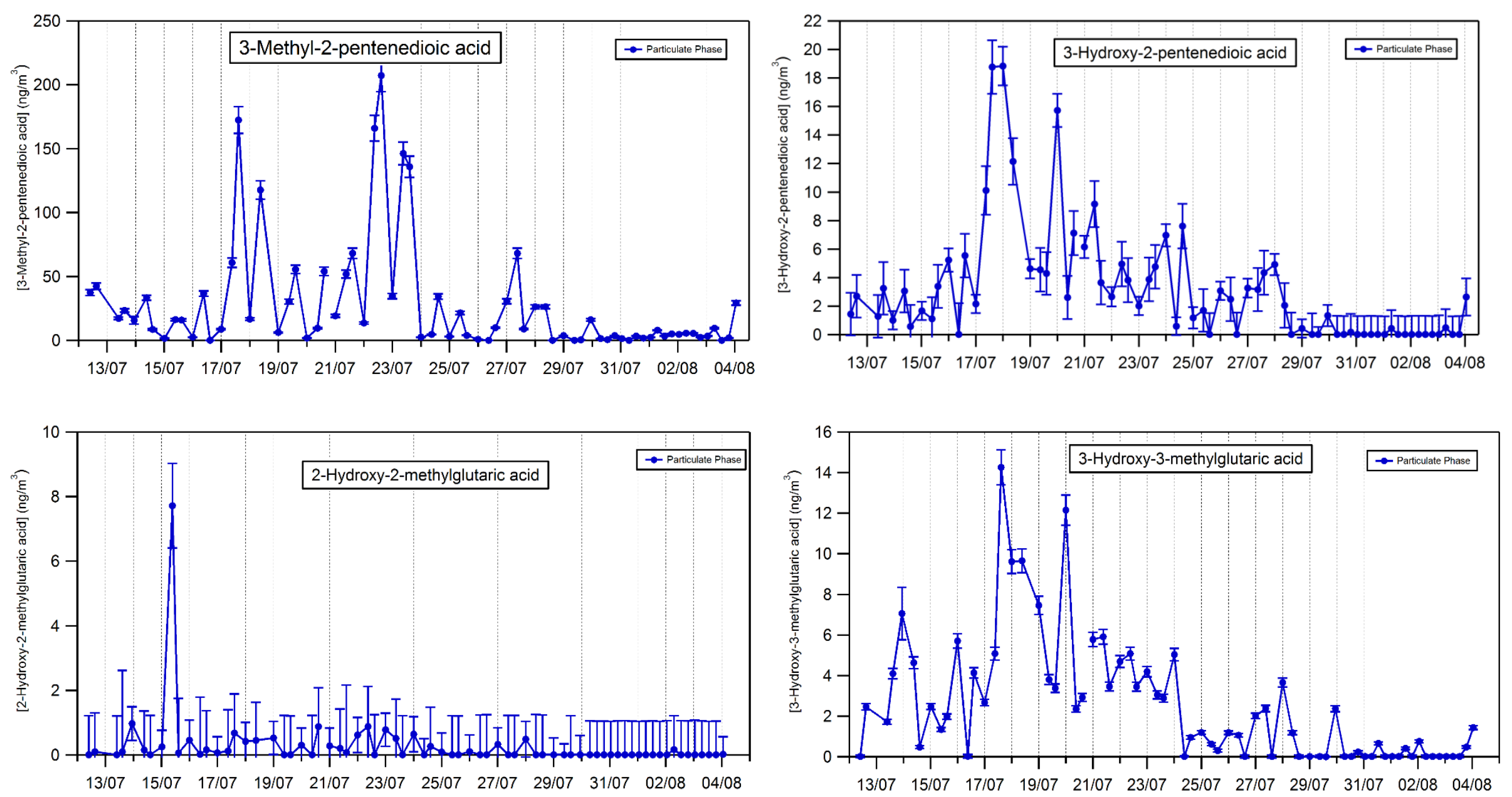

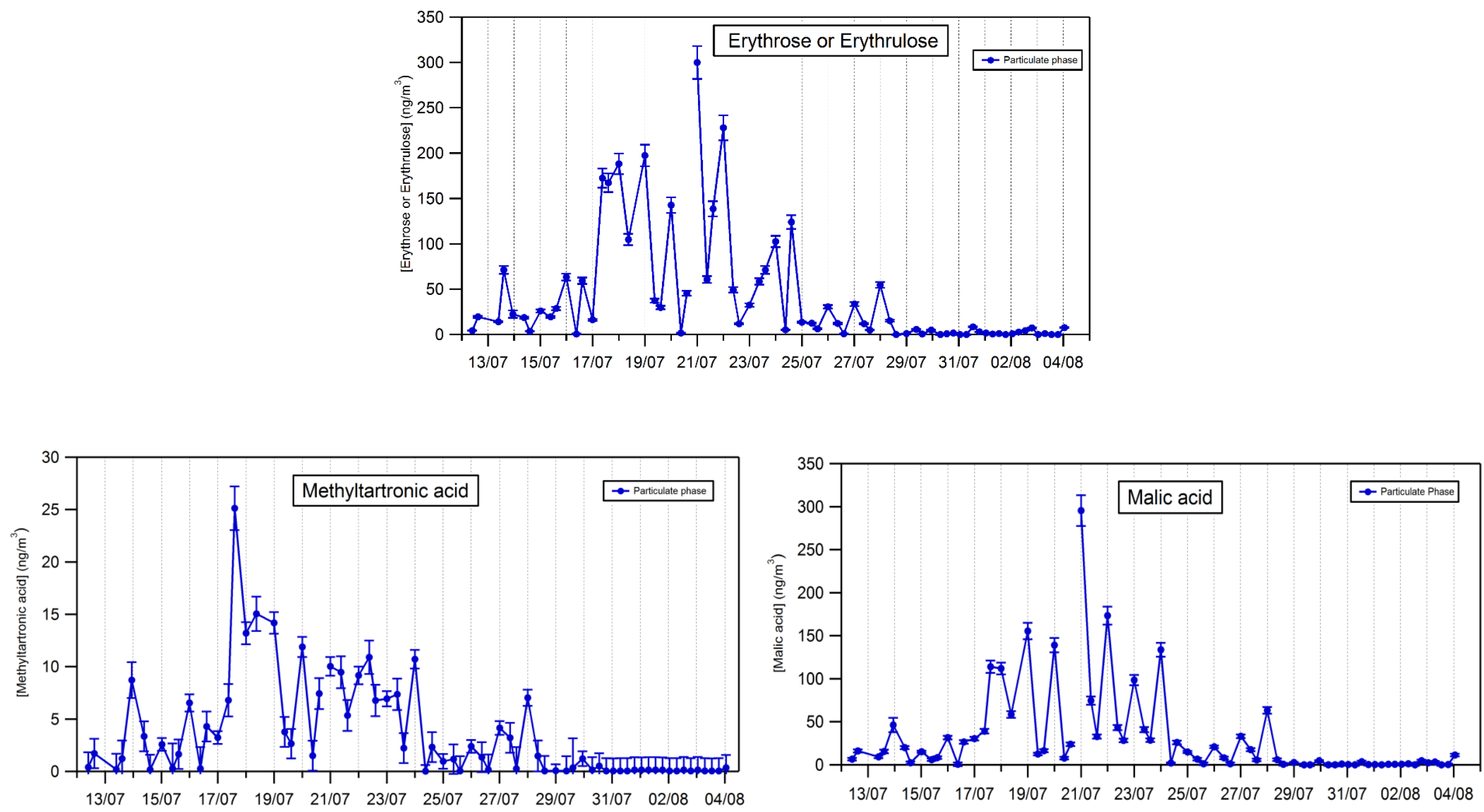

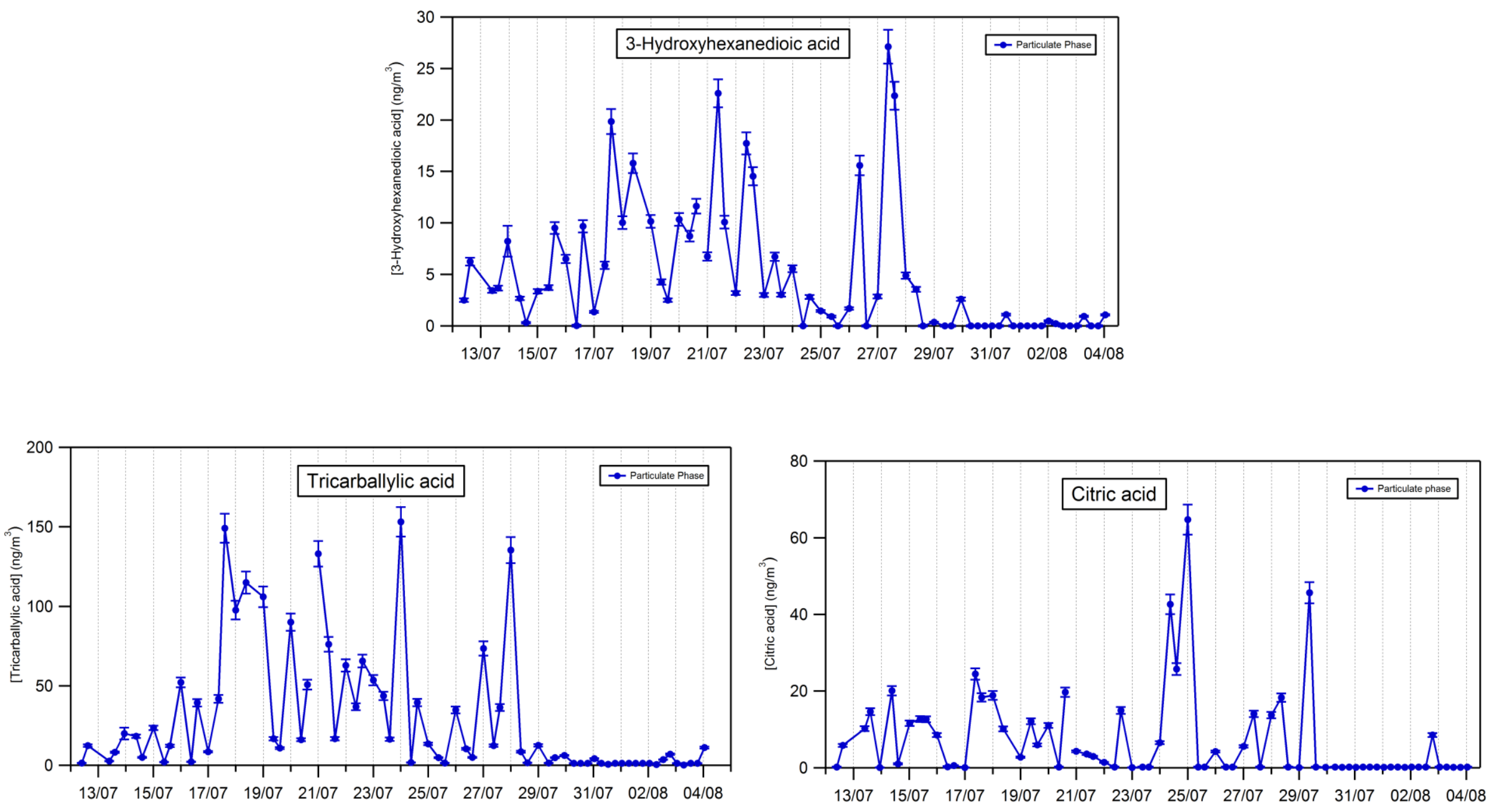

37 

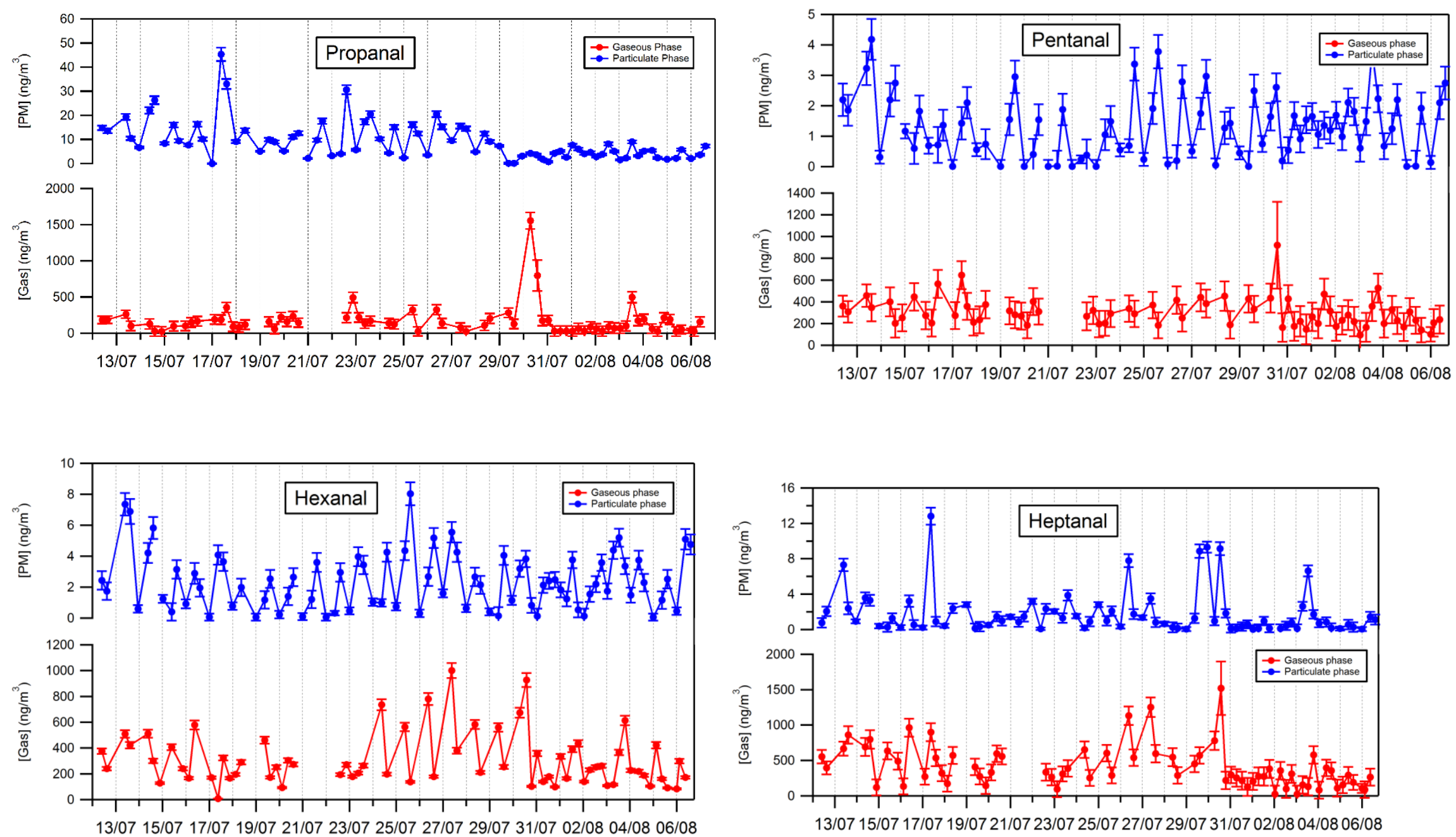

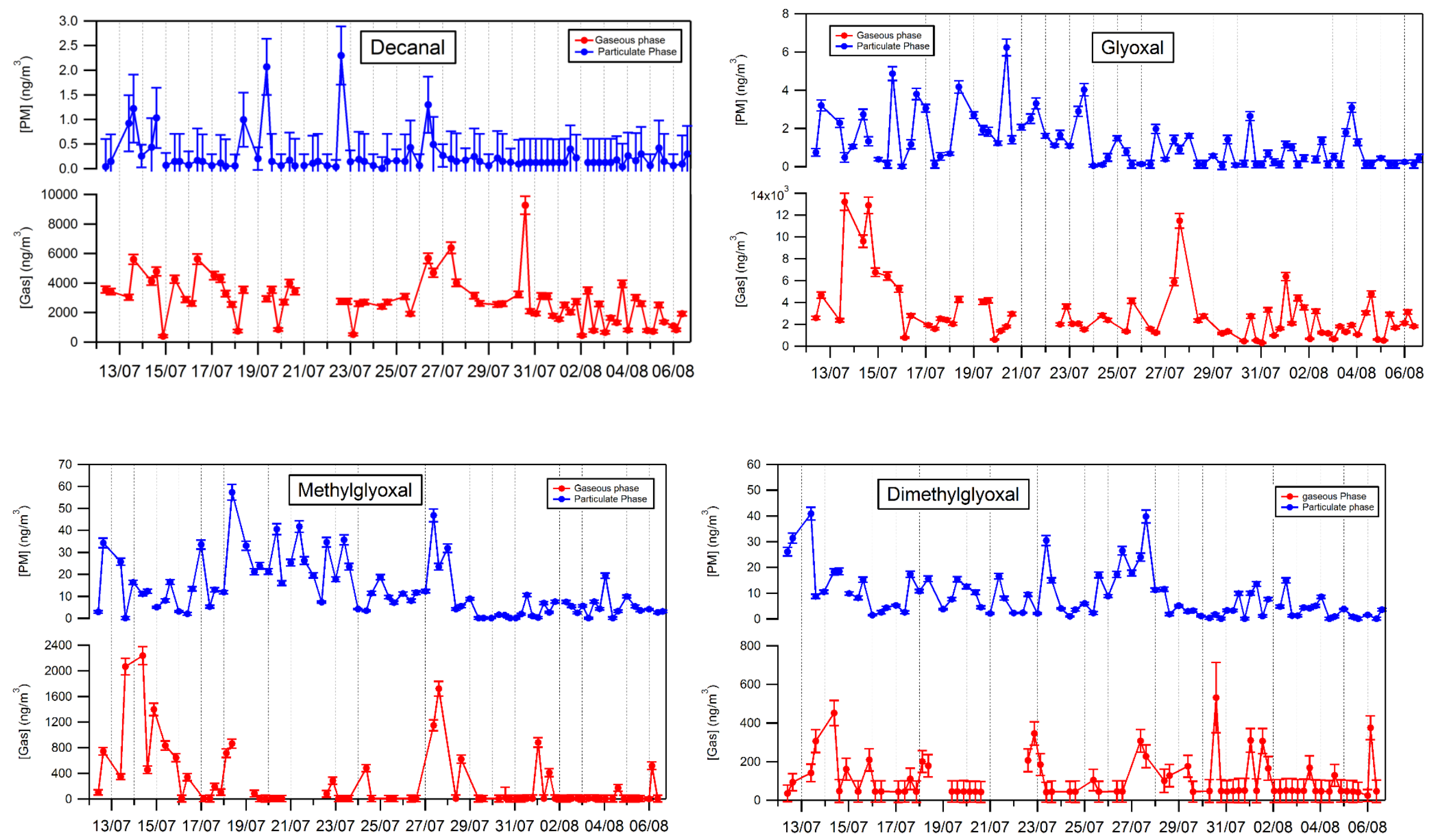

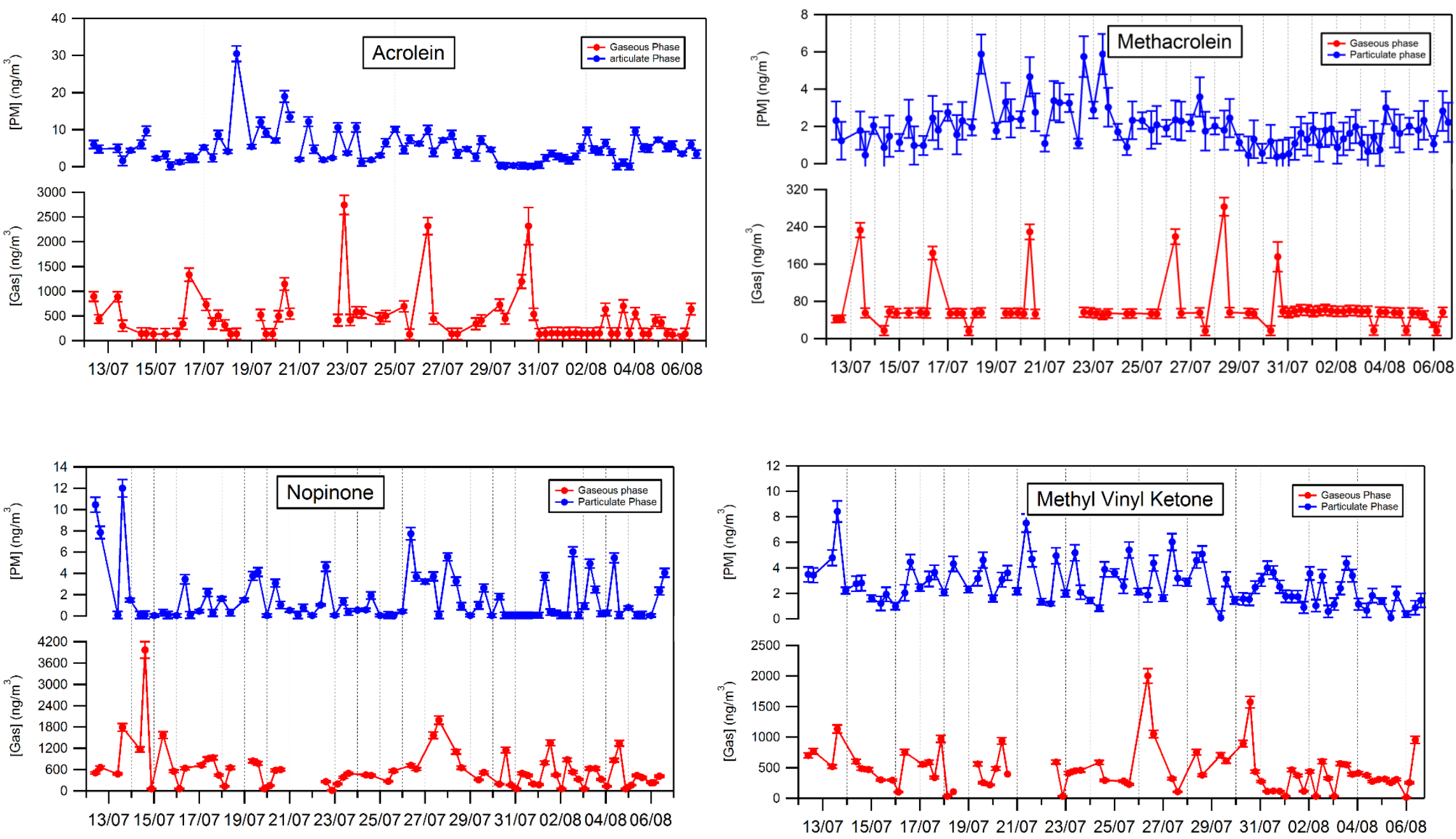

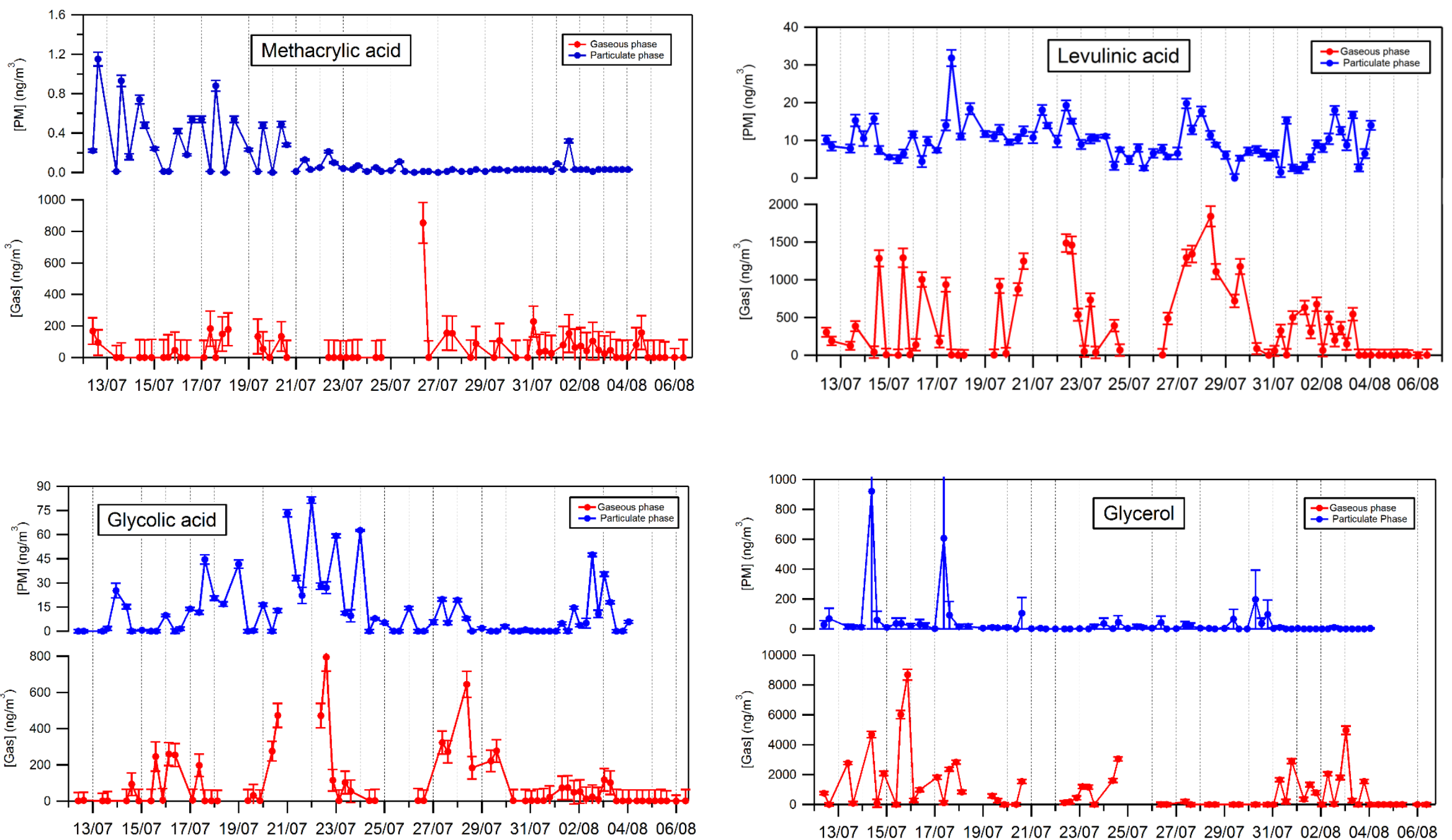
Sect. S7: Time series of MSA (methanesulfonic acid, black line) and water soluble HULIS (red line) during ChArMEx campaign.

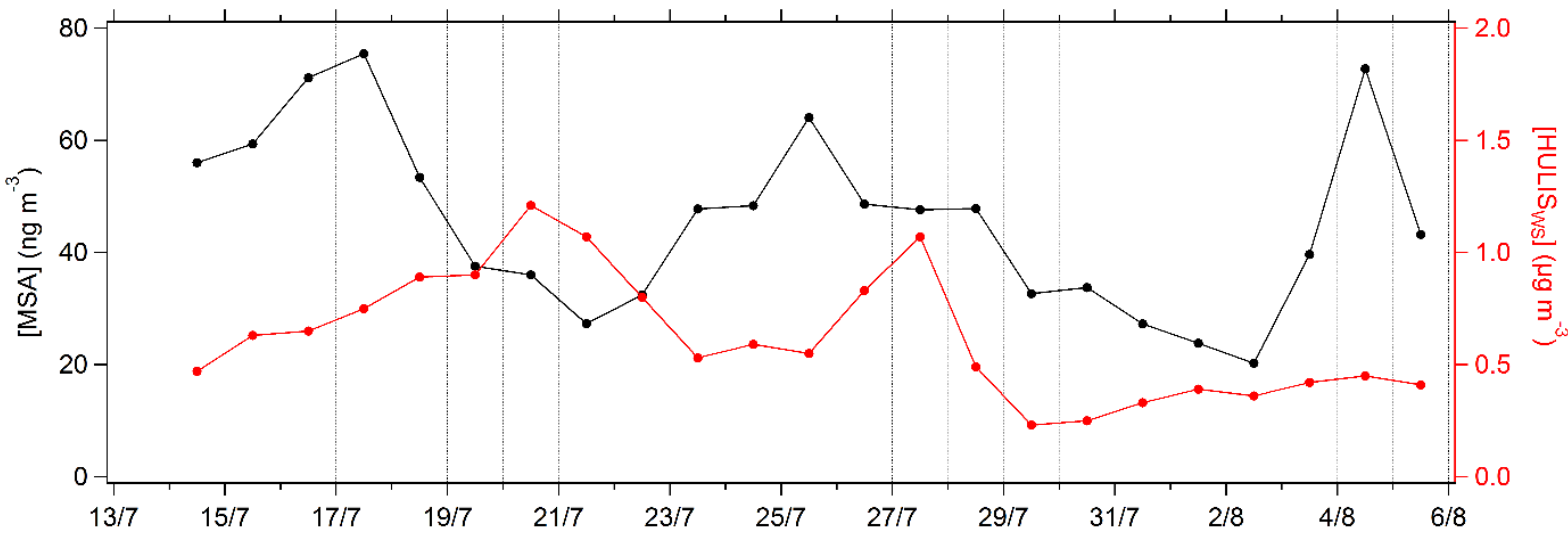




\section{References}

ACTRIS: Measurement Guideline VOC: WP4- NA4: Trace gases networking: Volatile organic carbon and nitrogen oxides Deliverable D4.1: Draft for standardized operating procedures (SOPs) for VOC measurements, 25-30, http://www.actris.net/Portals/97/deliverables/PU/WP4_D4.1_M12_v2.pdf (last access: 21 July 2020), 2012.

Baduel, C., Voisin, D., and Jaffrezo, J. L.: Comparison of analytical methods for Humic Like Substances (HULIS) measurements in atmospheric particles, Atmos. Chem. Phys., 9, 5949-5962, https://doi.org/10.5194/acp-9-5949-2009, 2009.

Bae, M.-S., Schauer, J. J., DeMinter, J. T., Turner, J. R., Smith, D., and Cary, R. A.: Validation of a semicontinuous instrument for elemental carbon and organic carbon using a thermal-optical method, Atmos. Environ., 38, 2885-2893, 2004.

de Gouw, J. and Warneke, C.: Measurements of volatile organic compounds in the earth's atmosphere using proton-transferreaction mass spectrometry, Mass. Spectrom. Rev., 26, 223-257, doi:10.1002/mas.20119, 2007.

El Haddad, I. : Fractions primaire et secondaire de l'aérosol organique primaire et secondaire de l'aérosol organique primaire et secondaire de l'aérosol organique: Méthodologies et application à un environnement urbain méditerranéen, Marseille, Université de Provence. [online] Available from: https://tel.archives-ouvertes.fr/tel-00589732/document (Accessed 25 January 2021), 2011.

El Haddad, I., Marchand, N., Wortham, H., Piot, C., Besombes, J.-L., Cozic, J., Chauvel, C., Armengaud, A., Robin, D., and Jaffrezo, J.-L.: Primary sources of PM2.5 organic aerosol in an industrial Mediterranean city, Marseille, Atmos. Chem. Phys., 11, 2039-2058, https://doi.org/10.5194/acp-112039-2011, 2011.

Ho, S. S. H. and Yu, J. Z.: Feasibility of Collection and Analysis of Airborne Carbonyls by On-Sorbent Derivatization and Thermal Desorption, Anal. Chem., 74(6), 1232-1240, doi:10.1021/ac015708q, 2002.

Jaffrezo, J. L., Calas, N., and Bouchet, M.: Carboxylic acids measurements with ionic chromatography, Atmos. Environ., 32, 2705-2708, 1998.

Michoud, V., Sciare, J., Sauvage, S., Dusanter, S., Léonardis, T., Gros, V., Kalogridis, C., Zannoni, N., Féron, A., Petit, J.-E., Crenn, V., Baisnée, D., Sarda-Estève, R., Bonnaire, N., Marchand, N., DeWitt, H. L., Pey, J., Colomb, A., Gheusi, F., Szidat, S., Stavroulas, I., Borbon, A., and Locoge, N.: Organic carbon at a remote site of the western Mediterranean Basin: sources and chemistry during the ChArMEx SOP2 field experiment, Atmos. Chem. Phys., 17, 8837-8865, https://doi.org/10.5194/acp-17-8837-2017, 2017.

Michoud, V., Sauvage, S., Léonardis, T., Fronval, I., Kukui, A., Locoge, N., and Dusanter, S.: Field measurements of methylglyoxal using proton transfer reaction time-of-flight mass spectrometry and comparison to the DNPH-HPLC-UV method, Atmos. Meas. Tech., 11, 5729-5740, https://doi.org/10.5194/amt-11-5729-2018, 2018.

Rossignol, S.: Développement d'une méthode de prélèvement simultané et d'analyse chimique des phases gazeuse et particulaire atmosphériques pour une approche multiphasique de l'aérosol organique secondaire, Paris 7. [online] Available from: http://www.theses.fr/2012PA077208 (Accessed 14 February 2016), 2012. 
Rossignol, S., Chiappini, L., Perraudin, E., Rio, C., Fable, S., Valorso, R. and Doussin, J. F.: Development of a parallel sampling and analysis method for the elucidation of gas/particle partitioning of oxygenated semi-volatile organics: a limonene ozonolysis study, Atmospheric Meas. Tech., 5(6), 14591489, doi:10.5194/amt-5-1459-2012, 2012.

Sciare, J., d'Argouges, O., Sarda-Estève, R., Gaimoz, C., Dolgorouky, C., Bonnaire, N., Favez, O., Bonsang, B. and Gros, V.: Large contribution of water-insoluble secondary organic aerosols in the region of Paris (France) during wintertime, J. Geophys. Res. Atmospheres, 116(D22), D22203, doi:10.1029/2011JD015756, 2011.

Sorooshian, A., Brechtel, F. J., Ma, Y. L., Weber, R. J., Corless, A., Flagan, R. C., and Seinfeld, J. H.: Modeling and characterization of a particle-into-liquid sampler (PILS), Aerosol Sci. Tech., 40, 396-409, 2006. 